\title{
The Relationship between Choline Bioavailability from Diet, Intestinal Microbiota Composition, and Its Modulation of Human Diseases
}

\author{
Natalia Arias ${ }^{1,2, *}$, Silvia Arboleya ${ }^{3}{ }^{-}$, Joseph Allison ${ }^{2}$, Aleksandra Kaliszewska ${ }^{2}$, \\ Sara G. Higarza ${ }^{1,4}\left(\mathbb{D}\right.$, Miguel Gueimonde ${ }^{3}(\mathbb{D})$ and Jorge L. Arias ${ }^{1,4}$ \\ 1 Instituto de Neurociencias del Principado de Asturias (INEUROPA), 33003 Oviedo, Asturias, Spain; \\ UO223953@uniovi.es (S.G.H.); jarias@uniovi.es (J.L.A.) \\ 2 Department of Basic and Clinical Neuroscience, Institute of Psychiatry, Psychology and Neuroscience, \\ King's College London, Denmark Hill, London SE5 8AF, UK; joseph.c.allison@kcl.ac.uk (J.A.); \\ aleksandra.kaliszewska@kcl.ac.uk (A.K.) \\ 3 Department of Microbiology and Biochemistry of Dairy Products, Instituto de Productos Lácteos de \\ Asturias (IPLA-CSIC), 33003 Oviedo, Asturias, Spain; silvia.arboleya@ipla.csic.es (S.A.); \\ mgueimonde@ipla.csic.es (M.G.) \\ 4 Laboratory of Neuroscience, Department of Psychology, University of Oviedo, Plaza Feijóo, s/n, \\ 33003 Oviedo, Asturias, Spain \\ * Correspondence: natalia.arias@kcl.ac.uk
}

Received: 14 July 2020; Accepted: 30 July 2020; Published: 5 August 2020

\begin{abstract}
Choline is a water-soluble nutrient essential for human life. Gut microbial metabolism of choline results in the production of trimethylamine (TMA), which, upon absorption by the host is converted into trimethylamine-N-oxide (TMAO) in the liver. A high accumulation of both components is related to cardiovascular disease, inflammatory bowel disease, non-alcoholic fatty liver disease, and chronic kidney disease. However, the relationship between the microbiota production of these components and its impact on these diseases still remains unknown. In this review, we will address which microbes contribute to TMA production in the human gut, the extent to which host factors (e.g., the genotype) and diet affect TMA production, and the colonization of these microbes and the reversal of dysbiosis as a therapy for these diseases.
\end{abstract}

Keywords: choline; TMA; TMAO; non-alcoholic steatohepatitis (NASH); cardiovascular disease (CVD); chronic kidney diseases (CKD); probiotics; gut microbiota; polyphenols; fecal microbiota transplantation

\section{Introduction}

Choline is an essential nutrient for humans throughout their life. Although humans can produce choline in small quantities through the hepatic phosphatidylethanolamine N-methyltransferase pathway, most individuals need to increase choline ingestion through their diet, in order to prevent deficiency [1-4]. The main dietary sources of choline include eggs, fish, grains, meat, milk, and their derived products, and to a lesser extent, some vegetables such as soybeans and potatoes $[1,3,5,6]$. In foods, choline is found as both water-soluble (free choline, phosphocholine, and glycerophosphocholine) and lipid-soluble (phosphatidylcholine and sphingomyelin) forms [7]; however, cooking methods can reduce the amount of choline content in the diet and increase the phosphatidylcholine contribution [8]. Different forms of choline influence the absorption and metabolism of this nutrient throughout development. Indeed, water-soluble forms that are mainly present in human milk enter the portal circulation and reach the liver, while lipid-soluble forms, 
which can be found in foods, are absorbed and transported through the lymphatic circulation [3,9]. Therefore, the intake of choline varies in accordance with different stages of development.

The majority of people do not meet the dietary requirements for choline, particularly those on vegetarian or vegan diets and pregnant or lactating mothers [1]. Lactation has been associated with an increased choline demand [10], whilst the maternal choline intake could be linked to enhanced placental health [11] and positive neurocognitive effects on the offspring [12]. Therefore, these sub-groups of people should be monitored closely in order to ensure appropriate choline intakes $[1,13,14]$.

Choline metabolism can be divided into four main pathways, which are involved in the synthesis of acetylcholine, betaine, phospholipids, and trimethylamine (TMA; overviewed in Figure 1) [3]. Choline metabolites have a wide range of functions in organisms [1,15]. Choline is catalyzed by choline acyltransferase into acetylcholine, which is key in cholinergic neurotransmission $[15,16]$. Moreover, choline can be oxidized to obtain betaine, which is an important osmolyte, a methyl donor implicated in the epigenetic regulation of DNA [15,17], and a requirement in the synthesis of phosphatidylcholine [3]. Special attention needs to be given to phosphatidylcholine, the most abundant phospholipid in the body, which is not only a major component of cellular membranes and needed for cell division and growth $[18,19]$, but also plays a role in cell signaling as a donor to synthesize sphingomyelin from ceramide $[18,20]$. Moreover, sphingomyelin is required for myelination processes in the nervous system [21].

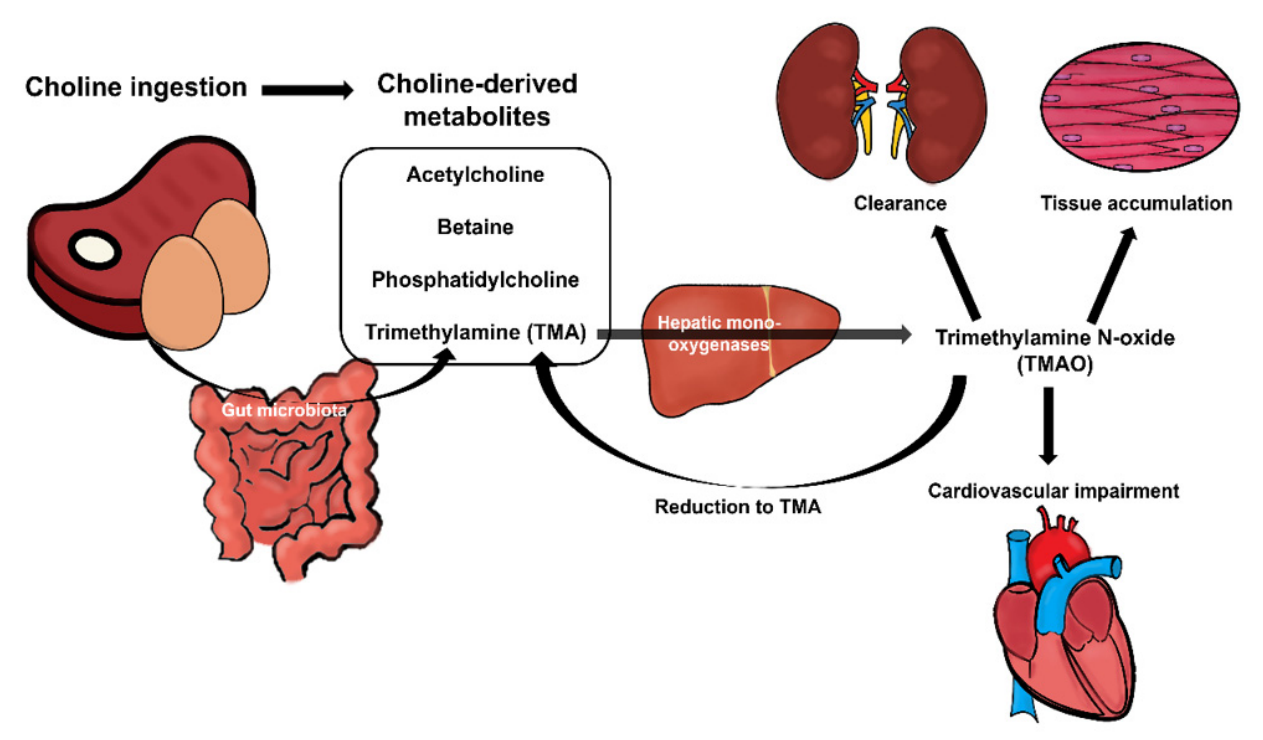

Figure 1. Overview of choline metabolism from the diet. Choline is taken from the diet and gut microbiota trimethylamine (TMA) lyases transform it into TMA. TMA is absorbed by the intestine and delivered to the liver, where TMA is metabolized into trimethylamine N-oxide (TMAO) by host hepatic monooxygenases. Finally, TMAO is distributed to organs, where it can be eliminated (kidneys) and accumulated (tissue). However, it could cause impairment in high concentrations (cardiovascular damage, for a detailed review see Section 5).

Moreover, we want to place a special emphasis on choline metabolism in the large intestine where it is metabolized to TMA by the gut microbiota prior to absorption [22]. The human microbiota harbors trillions of microbes including bacteria, archaea, viruses, phages, yeast, and fungi [23]. It starts to develop in the perinatal period and becomes diverse and complex in adulthood. Several intrinsic and extrinsic factors may affect the microbiota during infancy such as mode of delivery, the gestational age of birth, the infant feeding mode, the maternal diet, environmental factors such as family lifestyle and geographical location and host genetics, and adulthood such as physiological changes of the digestive tract, the modification of dietary patterns, and the impairment of the immune system $[24,25]$. These factors may disrupt the microbiota composition, causing so-called dysbiosis [26]. 
The composition of the adult human gut microbiota is mainly represented by the phyla Bacteroidetes and Firmicutes, followed by Actinobacteria, Proteobacteria, and Verrucomicrobia as minority phyla [25]. The gut is home to more than 1000 microbial species [27] and all of these bacteria encode a microbial gene pool, exceeding the size of the human genome, known as the microbiome [27]. The functions encoded in this microbiome expand the host's physiological potential, playing an important role in health and disease. This uniqueness of the host microbiota makes it difficult to devise therapies that can work across the population (see Section 6). This has led some authors to consider the intestinal microbiota as a "forgotten organ" [28]. The major function of the gut microbiota is to help in the harvesting of nutrients and energy from our diet. Moreover, it participates in the development of a host's immune system, brain, and behavior; protects against pathogens; and is a factory of bioactive compounds $[29,30]$.

As we have previously pointed out, among these bioactive compounds, the gut microbiota is able to produce TMA, which is absorbed in the intestinal epithelium and subsequently delivered to the liver through the portal circulation. There, it will be metabolized into trimethylamine N-oxide (TMAO) by host hepatic monooxygenases [31,32] such as flavin-containing monooxygenases 3 (FMO3) [33]. Ultimately, TMAO is distributed throughout the body so that it can accumulate in tissues as an osmolyte [34,35] whilst the rest of it is mostly cleared by the kidney, which is in charge of excreting it through the urine (overviewed in Figure 1) [34].

Therefore, choline is important for the function and structure of membranes including their signaling, transport, and repair [36-38]. Moreover, as we have previously mentioned, it is the key in the synthesis of acetylcholine, methylation, gene expression [39], and liver and muscle function [36]. However, it has recently gained attention due to its association with adverse health outcomes [3]. Currently, the identification of the type of bacteria involved in TMA synthesis and the mechanisms by which choline and its metabolites TMA and TMAO contribute to the risk of disease need to be properly evaluated, in order to understand choline's impact on health.

In this review, we will revisit the relationship between gut microbiota populations and circulating TMA and TMAO levels, highlighting not only the microbiota genetics behind these changes but also how host genetics can influence the gut microbiome. We will also discuss the relationship between choline-microbiota changes and their impact on different diseases as well as explore microbial modulation as a potential therapeutic treatment.

\section{The Impact of Gut Microbiota on Choline Metabolism}

The ingestion of food containing choline or other trimethylamine-containing compounds is followed by the synthesis of TMA in the gut by microorganisms including both Gram-positive and Gram-negative bacteria (Figure 2). Therefore, the magnitude of the production of TMA is influenced by the composition of the microbiota of the individual. It is important to note that only a minor fraction of the microorganisms present in the intestine (less than 1\%) harbor the genes required for TMA production [40]. However, even very low concentrations of these microorganisms seem to be sufficient for TMA production, which illustrates the importance of the gut microbiota in this context [41]. Indeed, the presence of increased TMA and TMAO levels has been associated with higher activity of bacterial members of the phylum Firmicutes and Proteobacteria, which are known producers of this metabolite [40,41]. Moreover, TMA and TMAO levels have been linked to an elevated Firmicutes/Bacteroidetes ratio with higher levels of Firmicutes and lower levels of Bacteroidetes [42,43] due to the inability of Bacteroidetes to produce TMA [44,45]. 


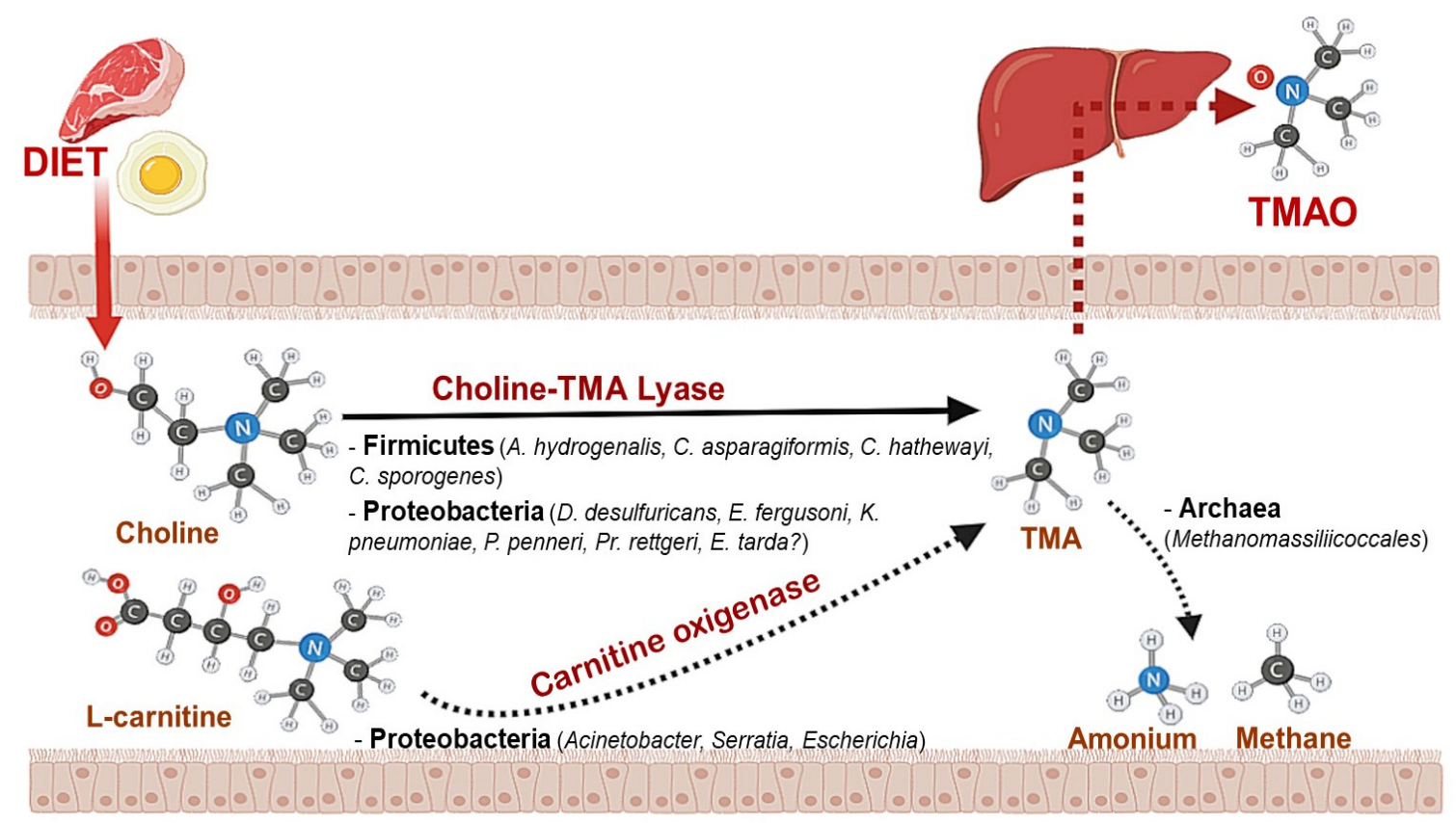

Figure 2. Microorganisms involved in the metabolism of dietary choline and other trimethylamine-containing compounds. Following ingestion of foods containing choline/lecithin, or L- carnitine, certain intestinal microorganisms metabolize these compounds to trimethylamine (TMA) by different metabolic pathways. TMA can then be absorbed and transformed into trimethylamine $\mathrm{N}$-oxide (TMAO) in the liver, or it can be reduced by methanogenic archaea in the gut to produce methane and ammonium.

Recently, the genetics that underpin TMA production in the microbiota has received a great deal of attention. This has led to the identification of different gut microbial genes and gene-clusters involved in the catabolic reactions converting dietary compounds into TMA. Among them, the cluster $\mathrm{CutC} / \mathrm{CutD}$, which codes for the choline TMA-lyase and its activating protein [46], seems to be key in the intestinal environment [47], whereas the carnitine oxygenase (CntA) contribution to TMA production is lower [48].

Moreover, betaine (choline-derived metabolite) reduction by the action of the microbial enzyme glycine betaine reductase coded by the gene $\mathrm{GrdH}$ seems to play a minor role in TMA production in the gut [40]. This also seems to be the case for the production of TMA via the intermediate $\gamma$-butyrobetaine derived from carnitine by the action of the YeaW/YeaX cluster [49].

Although the $\mathrm{CutC} / \mathrm{CutD}$ cluster appears to be the most widely distributed mechanism for TMA production from choline, it has been demonstrated that a quarter of TMA production is linked to $C n t A$, which is present in lower amounts [32]. Moreover, a recent study [40], in which mammal species were compared, revealed that herbivores harbor a lower relative abundance of $C u t C$ while lacking $\mathrm{CntA}$. These results point to the influence of the evolving relationship between host genetics and diet in the prevalence of these genes, as illustrated by the differences between herbivores and carnivores. It is also important to note that our knowledge in this area is limited and some pathways involved in TMA production are still unknown. Supporting this, Wu et al. [50] found no association between $\mathrm{CntA}$ and serum TMAO levels after carnitine consumption, suggesting that other pathways such as the $\gamma$-butyrobetaine pathway may also be of relevance in the gut environment. In addition, the lack of any known TMA-producing gene in Edwardsiella tarda—a known TMA-producing microorganism—also suggests the existence of other unknown pathways [47].

Regarding the microbial taxa harboring these genes, it was found that the cluster $\mathrm{CutC} / \mathrm{CutD}$ is the most widely distributed, not only being present in a variety of intestinal microorganisms, in particular in Firmicutes, especially the Clostridium cluster XIVa and Eubacterium strains, but even in some Actinobacteria and Proteobacteria [40]. GrdH also seems to be mainly distributed among Firmicutes, 
but it has been found in some Spirochaetes. On the contrary, the presence of $C n t A$ and YeaX/Y is mainly associated with the bacterial phyla of Proteobacteria, with Escherichia and Acinetobacter being the main genera harboring these genes in the human gut [40].

In the specific case of choline metabolism, TMA is formed through the action of the microbial choline TMA-lyase (Figure 3) [51]. Specifically, the intestinal bacteria in charge of TMA production from choline include Anaerococcus hydrogenalis, Clostridium asparagiformis, Clostridium hathewayi, Clostridium sporogenes, Desulfovibrio desulfuricans, Escherichia fergusoni, Ed. tarda, Klebsiella pneumoniae, Proteus penneri, and Providencia rettgeri [41,52].

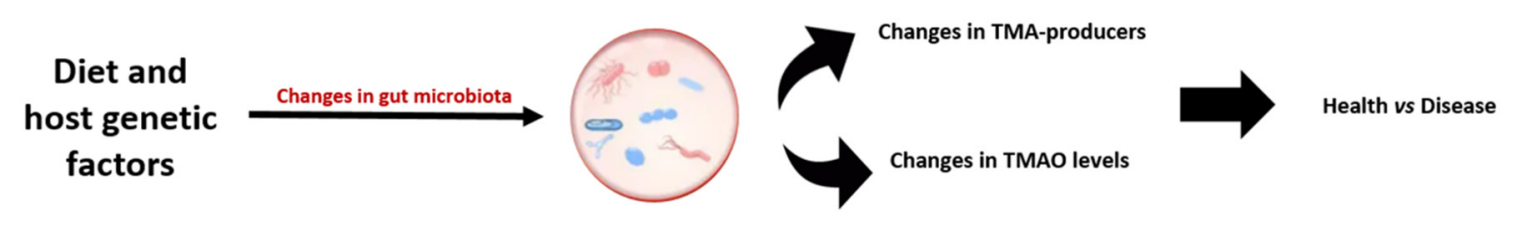

Figure 3. Overview of factors affecting gut microbiota and direct effects on TMAO levels.

Once TMA is formed, it will be subsequently oxidized into TMAO in the liver through the enzyme FMO3 [53]. It is worth noting that some bacteria from the phylum Proteobacteria may also be able to metabolize the TMAO ingested via the diet into TMA via TMAO reductase using metabolic retroconversion [54]. Finally, it has recently been found that intestinal archaea such as some members of the order Methanomassiliicoccales are able to reduce TMAO to methane [55]. Therefore, a current area of research relies on the use of such microorganisms as potential probiotics, in order to reduce the circulating levels of TMAO, which have been associated with an increased cardiovascular disease risk.

\section{Diet Impact on Microbiota-Choline Metabolism}

It has been demonstrated that the composition and diversity of gut microbiota can be influenced by the diet, since it is, in turn [56], an important source of variability in serum TMAO levels. In this regard, long-term individual dietary habits have been proven to influence microbiota enterotypes $[57,58]$. Indeed, Wu et al. [58] observed that a Western diet consumption-typically represented by a high consumption of animal proteins, saturated fats, and low fiber-was associated with the Bacteroides enterotype, whereas a carbohydrate-based diet mainly consumed by agrarian societies, was linked to a Prevotella enterotype. Western diets are characterized by animal products such as liver, pork meat, and eggs, which contain large amounts of choline [59] and are known not only to increase blood and urine TMAO levels [41] but even have an effect on the gut microbiota. In fact, Manor and colleagues [60] observed a positive correlation between intestinal microbial clades such as Neisseriaceae or Desulfovibrio and TMAO levels, which were also elevated in symptomatic coronary vascular disease (CVD) patients and those consuming an animal-based diet. Another study from Cho et al. [42] reported that men with elevated levels of TMAO in the body after consuming dietary eggs tended to have a higher abundance of Firmicutes; meanwhile, individuals with lower levels of TMAO exhibited a higher abundance of Bacteroidetes.

Similar differences in microbiota and TMAO levels have been reported between vegetarian and omnivorous diets, which were also accompanied by a lesser ability to produce TMA in vegetarians [61]. These observations reinforce the potential of modulating dietary habits to reduce the risk associated with high TMAO levels.

Nevertheless, due to the importance of choline as an essential nutrient, choline-deficient diets may also induce gut microbiota alterations and health problems [62-65]. Indeed, a human trial in which the choline intake was controlled demonstrated that the gut microbiota composition changed with dietary choline levels and specific alterations in Gammaproteobacteria, and Erysipelotrichi members were associated with changes in liver fat during choline depletion [66]. These results confirm the impact of diet on both gut microbiota and TMAO levels $[61,66]$. In addition, it has been reported that FMO3 
expression is closely related to the composition of intestinal flora $[53,67]$. The changes observed after choline-dietary interventions, together with the putative host's genes, could be used for predicting and modulating the risk of developing diseases related to this nutrient (overviewed in Figure 3).

\section{Host Genotype Impact on Microbiota Choline Metabolism}

The concentration of TMA/TMAO in plasma has been linked to the composition of intestinal microbiota and differences among microbiota enterotypes [57] have been proposed [68]. Nevertheless, it may be considered that the high inter-individual variability in the composition of the intestinal microbiota results in a large variability in its enzymatic capabilities [69]. Furthermore, this inter-individual variability is linked to different factors including the host's genetics.

Over a period of decades, different studies have tried to understand how a host's genetic background may influence the overall microbiome. The proportion of phenotypic variation in a trait that is attributable to genetic variation among individuals is known as heritability [70]. Among the gut microbiota, a few bacteria and archaea have arisen as heritable and have been associated with host genes. In line with this, twin studies have observed a higher similarity in the gut microbiota composition between monozygotic than dizygotic twins, which is attributable to shared genes. These studies also identified heritable bacteria including Christensenellaceae (later associated with a low body mass index), the methanogenic Archaea Methanobrevibacter smithii, and the genus Blautia [71,72]. Moreover, microbiome genome-wide association studies have also identified associations between human genes and the gut microbiome such as the lactase gene LCT and the abundance of Bifidobacterium [73,74] or the vitamin D receptor gene and microbial diversity [75].

Focusing on how host genetics can influence the gut microbiome in a disease context, several associations between specific single nucleotide polymorphisms or genetic variants of host genes and intestinal bacteria have been identified (Table 1). These support the idea that host genes involved in the digestion of sugars, dietary preference, and immunity can alter the composition of the gut microbiome [76-81]. There is a lack of knowledge on the relationship between host genetics and gut microbiota in choline-mediated diseases. However, regarding liver diseases, one study has identified a quantitative traci loci (QTL) in chromosome 7 of the mouse genome (MM7) that showed genome-wide linkage with the relative abundance of Turicibacter, which was overlapped with the HCS1 QTL for susceptibility to murine hepatocellular carcinomas [82]. This opens up the door to investigate how specific host genes mediate an altered gut microbiota composition, contributing, in this way, to its abnormal function and the development of diseases such as those studied in this review.

Moreover, genotype-associated differences in TMAO and TMA levels were also suggested in a murine model. Romano and colleagues [41] observed higher levels of serum TMAO in female mice, which were associated with higher relative abundances of TMA-gut microbial producers rather than their male counterparts. These gender-associated variances were attributed to the higher hepatic flavin-containing mono-oxygenase (FMO) activity in females, in line with other studies [53,69]. However, contradictory results were found for the TMAO concentration related to gender differences in humans, which have been linked to several confounding variables such as age, body mass, and blood pressure [34]. 
Table 1. Host genetic variants with an effect on the gut microbiota (adapted from Spor et al., 2011 [70]).

\begin{tabular}{|c|c|c|}
\hline Host Genetic Variant & Gut Microbiota Impact & Diseases or Adverse Phenotypes \\
\hline $\begin{array}{l}\qquad M E F V \\
\text { encodes pyrin, one of the regulators of innate immunity [83] }\end{array}$ & $\begin{array}{c}\text { Changes in bacterial community structure, mainly in } \\
\text { Bacteroidetes, Firmicutes, and Proteobacteria; loss of } \\
\text { bacterial load and diversity depended on the allele } \\
\text { carrier status of the host [83] }\end{array}$ & $\begin{array}{l}\text { Mutations in MEFV: Familial Mediterranean fever } \\
\text { (autoinflammatory disorder) [83] }\end{array}$ \\
\hline $\begin{array}{c}\text { APOA1 } \\
\text { major component of the high-density lipoprotein (HDL) [84] }\end{array}$ & $\begin{array}{l}\text { Changes in community structure in APOA1-deficient } \\
\text { mice [84] }\end{array}$ & $\begin{array}{l}\text { SNPs in APOA1: risk of obesity, cardiovascular } \\
\text { disease, and hyperlipidemia [84] }\end{array}$ \\
\hline $\begin{array}{c}\text { MyD88 } \\
\text { adaptor for multiple innate immune receptors that recognize } \\
\text { microbial stimuli [85] }\end{array}$ & $\begin{array}{c}\text { Change in distal gut microbiota composition: higher } \\
\text { Lactobacillaceae, Rikenellaceae, and Porphyromonadaceae } \\
\text { abundances in MYD88-deficient mice [85] }\end{array}$ & $\begin{array}{l}\text { Loss of MYD88: comprised innate immune response } \\
\text { to pathogens [85] }\end{array}$ \\
\hline $\begin{array}{c}\text { NOD2 } \\
\text { intracellular pattern recognition receptor of muramyl } \\
\text { dipeptide constitutively expressed in human Paneth cells [86] }\end{array}$ & $\begin{array}{l}\text { Increased load of commensal resident bacteria in } \\
\text { Nod2-deficient mice and shifts in the relative } \\
\text { frequencies of Faecalibacterium and Escherichia [86] }\end{array}$ & $\begin{array}{l}\text { Mutations in NOD2: risk factor for Crohn's disease } \\
\text { and diminished ability to prevent intestinal } \\
\text { colonization of pathogenic bacteria [86] }\end{array}$ \\
\hline $\begin{array}{l}\text { HLA } \\
\text { proteins that are encoded by the major histocompatibility } \\
\text { complex (MHC) gene complex in humans [87] }\end{array}$ & $\begin{array}{c}\text { Correlation between higher genetic risk and bacterial } \\
\text { groups: Streptococcus-Lactococcus, E. rectale-C. coccoides, } \\
\text { Clostridium, Bacteroides-Prevotella groups and total } \\
\text { Gram-negative bacteria [87] }\end{array}$ & Variation in HLA genes: risk of celiac disease [87] \\
\hline $\begin{array}{l}\qquad \text { SLC39A8 } \\
\text { encodes alanine or threonine at position } 391 \text { in the zinc } \\
\text { transporter solute carrier family 39, member } 8 \text { protein [76] }\end{array}$ & $\begin{array}{l}\text { Association between the risk locus that carries } \\
\text { SLC39A8 and the abundance of Anaerostipes, } \\
\text { Coprococcus, and Lachnospira [76] }\end{array}$ & $\begin{array}{c}\text { Variants of SLC39A8: associated with inflammatory } \\
\text { bowel disease (IBD) and distinct phenotypes } \\
\text { including obesity, lipid levels, blood pressure, and } \\
\text { schizophrenia [76] }\end{array}$ \\
\hline $\begin{array}{c}\alpha-\text { defensin } \\
{[88]}\end{array}$ & $\begin{array}{l}\text { Alpha-defensin-dependent changes in microbiota } \\
\text { composition, but not in total bacterial numbers. } \\
\text { Lower segmented filamentous bacteria numbers [76]. }\end{array}$ & $\begin{array}{c}\text { Changes in the copy numbers in defensin genes: } \\
\text { Crohn's disease [88]. }\end{array}$ \\
\hline $\begin{array}{c}\text { IgA locus }> \\
{[89]}\end{array}$ & $\begin{array}{l}\text { Predominant and persistent expansion of segmented } \\
\text { filamentous bacteria throughout the small intestine in } \\
\text { activation-induced cytidine deaminase, which } \\
\text { produces an absence of IgA [89]. }\end{array}$ & $\begin{array}{c}\text { Lack of IgA: higher incidence of inflammatory bowel } \\
\text { diseases [89] }\end{array}$ \\
\hline
\end{tabular}




\section{Choline Intake and Its Relationship to Disease}

As previously mentioned, TMAO is correlated with disease and all-cause mortality [90,91]. Low serum TMAO induced by choline-deficits diets is associated with non-alcoholic steatohepatitis (NASH), while high concentrations of TMAO are associated with CVD and chronic kidney disease (CKD). Here, we will discuss the mechanisms through which varying levels of choline intake cause disease (overviewed in Figure 4).

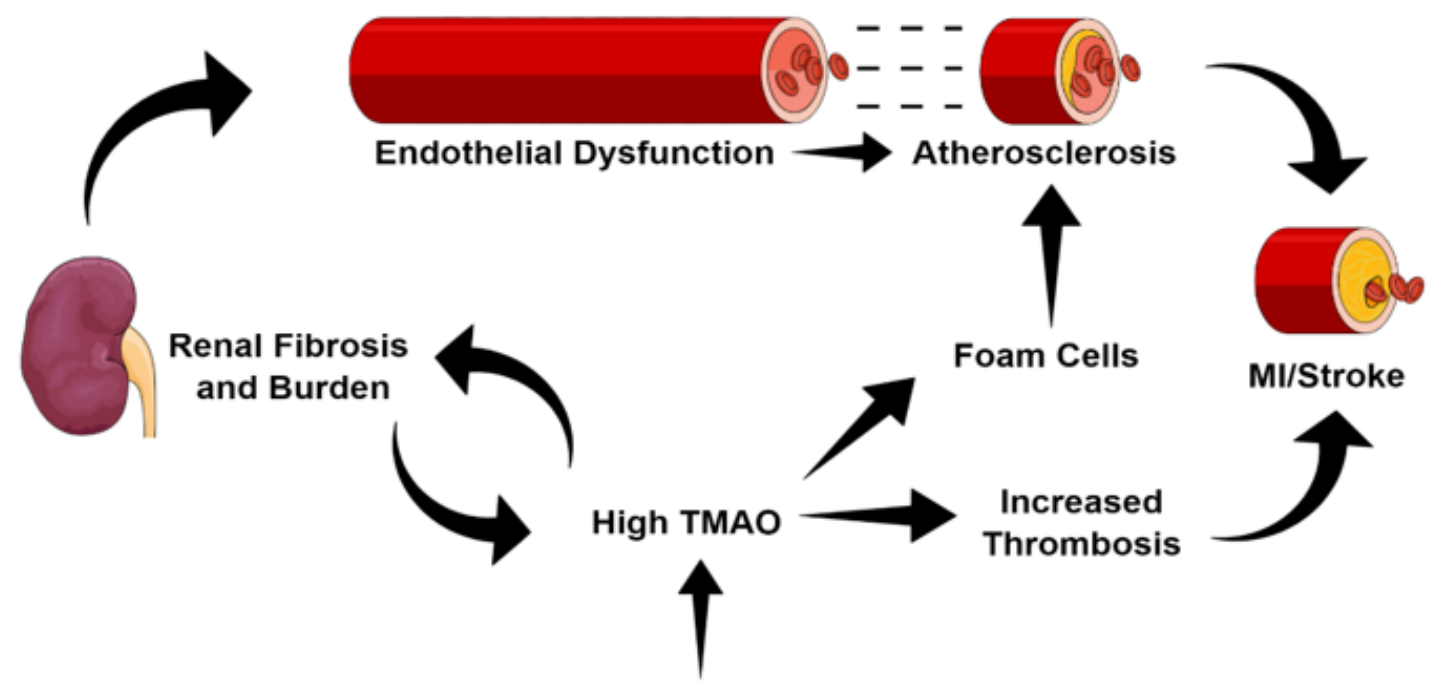

\section{Choline}

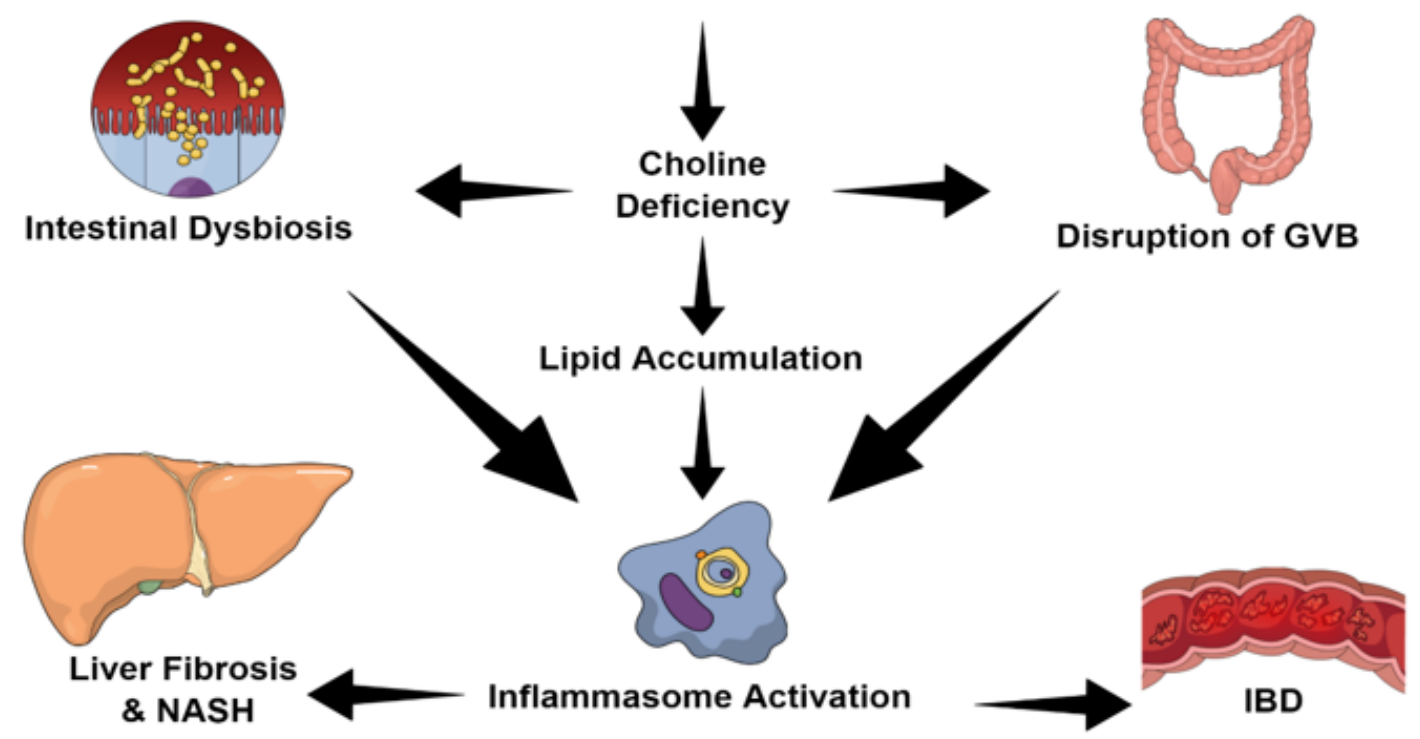

Figure 4. An overview of the ways in which choline intake may cause disease. Abbreviations: GVB, gut vascular barrier; IBD, inflammatory bowel disease; MI, myocardial infarction; NASH, non-alcoholic steatohepatitis; TMAO, trimethylamine-N-oxide.

Average plasma TMAO in humans is around $3.3 \mu \mathrm{M}$; however, this can vary greatly after the intake of certain foods that are rich in choline and returns to the baseline within a few hours [35]. CKD sufferers often have persistent exaggerated levels of plasma TMAO, although, following a kidney transplant, the TMAO concentration was shown to reduce to almost control levels [91,92]. However, it remains unclear whether this is simply a marker of renal impairment or whether TMAO plays an active role in renal function. Tang et al. [93] found an upregulation of phosphorylated Smad3, a profibrotic marker, and KIM-1 (kidney injury marker) in male mice fed choline- and TMAO-supplemented diets [94]. 
This was accompanied by increased collagen deposition and tubulointerstitial fibrosis, suggesting that high levels of TMAO may result in renal pathology and subsequent impairment such as endothelial dysfunction $[93,95]$.

The inability to regulate the vascular tone is an early marker of CVD and may lead to atheroma-development. Mice fed a choline-supplemented diet displayed significantly less reverse cholesterol transport with reductions in mRNA of Cyp7a1 and Cyp27a1. This attenuated the conversion of cholesterol into bile acids, resulting in cholesterol build-up [68]. Furthermore, increased TMAO levels upregulate macrophage scavenger receptors such as CD36 and the recruitment of leukocytes [34,96,97]. Together, these promote the formation of foam cells, which build-up to form atherosclerotic plaques [98]. With the build-up of atheroma, myocardial infarction and stroke present the greatest risk, with thrombi more likely to occlude the entire arterial lumen [31,90,99]. Following arterial injury, choline-rich diets reduce the time required for vessel occlusion, which is accomplished by the TMAO-induced release of intracellular calcium ions into the cytosol of platelets, thereby activating platelets and promoting adhesion [31,99].

Rises in TMAO related with CKD and CVD have been associated with an increased abundance of TMA-producing bacteria [60]. Romano and colleagues [100] have suggested that choline-consuming microbiota compete with the host for choline, in order to produce TMA, and thereby reduce the bioavailability of this nutrient. Subsequently, this leads to a reduction in S-adenosylmethionine (SAM) methyl-donor groups, for which choline is a major source. The loss of methyl donors may cause epigenetic dysregulation and hypomethylation of the host's genome [100,101]. Indeed, the global hypomethylation of DNA has been associated with CKD and atherosclerosis [102,103]. Equally, hypermethylation has also been correlated with CKD and therefore illustrates the complexity of epigenetic regulation and the need for further research [104,105]. Interestingly, Romano [100] found that maternal epigenetic profiles can be passed on to offspring through pregnancy and may alter the offspring's epigenome in utero. This may have long-term post-natal effects such as behavioral and cognitive changes $[100,101,106,107]$. The potential for nutritional intake to have inter-generational impacts through epigenetic profiles is highly undocumented territory and may present one way through which parent biology may affect the offspring long-term, independent of the genotype.

Choline-deficient diets have also been associated with NASH and may result in obesity and hyperglycemia [64-66,108]. Research indicates the role of choline-deficient diets in intestinal dysbiosis by reducing the microbiota diversity and altering the microbial population representation within the microbiome $[64,65,109]$. Subsequent transplantation of the microbiome of NASH individuals is sufficient in inducing NASH in otherwise healthy individuals $[65,110]$.

Choline-deficient diets interfere with and disrupt the intestinal barrier [64,111,112]. Downregulation of the Wnt/ $\beta$-Catenin pathway following a methionine-choline-deficient diet (MCD) results in disruption of the gut vascular-barrier (GVB) and upregulation of PV1, a marker of GVB [112,113]. In addition, zona occludens-1, a tight junction protein and permeability marker, is lower in those receiving a MCD diet $[109,114]$. This increases bacterial infiltration from the gut into peripheral organs such as the liver and leads to steatosis and lipid accumulation.

Lipid accumulation may be a result of reductions in fatty acid esterification genes, which prolong the half-lives of injury-inducing lipids $[115,116]$. Moreover, the downregulation of genes in very-low-density lipoprotein (VLDL) secretion and reduced phosphatidyl choline and triglyceride contents of VLDLs promote the build-up of cholesterol and fats in the liver [116-118]. These surplus fatty acids may promote the activation of inflammasomes [119].

Dysregulation in the microbiome is correlated with the activation of the Nod-like receptor protein 3 (NLRP3) inflammasome which is necessary for fibrosis in developing NASH pathology [120]. Moreover, NLRP3 activation may be involved in patients suffering from inflammatory bowel disease (IBD). In this regard, it has been demonstrated that an elevation of NLRP3 levels exacerbates inflammation in colitis mouse models for IBD [121]. Despite this, NLRP3 deficiency has been seen to both exacerbate and attenuate intestinal inflammation, highlighting the complexity of NLRP3's role in inflammation [122]. 
Abnormal choline-intake is involved in the pathogenesis of major debilitating diseases such as CKD, CVD, and NASH (Table 2). Despite an overwhelming amount of evidence demonstrating correlations between choline, and its metabolite TMAO, in terms of disease onset, it is not uncommon to see conflicting data and reports of no correlation between them. Some inconsistencies revolve around L-carnitine and betaine showing protective effects against CVD and therefore casts doubt on TMAO's involvement. However, we cannot rule out the possibility that betaine or L-carnitine have some regulatory effect on TMAO that reduces the proatherogenic effect of TMAO just as much, as these studies suggest that TMAO is beneficial $[123,124]$. As a result, these present an inherent problem when trying to draw conclusions about the effects of choline intake on disease. Historically, it has been impractical to measure choline levels alongside TMAO and TMA concurrently. Despite TMA being the main intermediate in the formation of TMAO, it is not routinely tested for (with TMAO being preferred). It is possible that studies that report no correlation with TMAO may instead show correlations between TMA and disease $[125,126]$. In line with this, a new methodology by Wu and colleagues [127] allows for the simultaneous measurement of TMA and TMAO and provides the opportunity to establish the exact role and associations of these choline metabolites and disease in future research. 
Table 2. Summary of the association between disease, TMAO levels, and their effects on metabolites and microbiota.

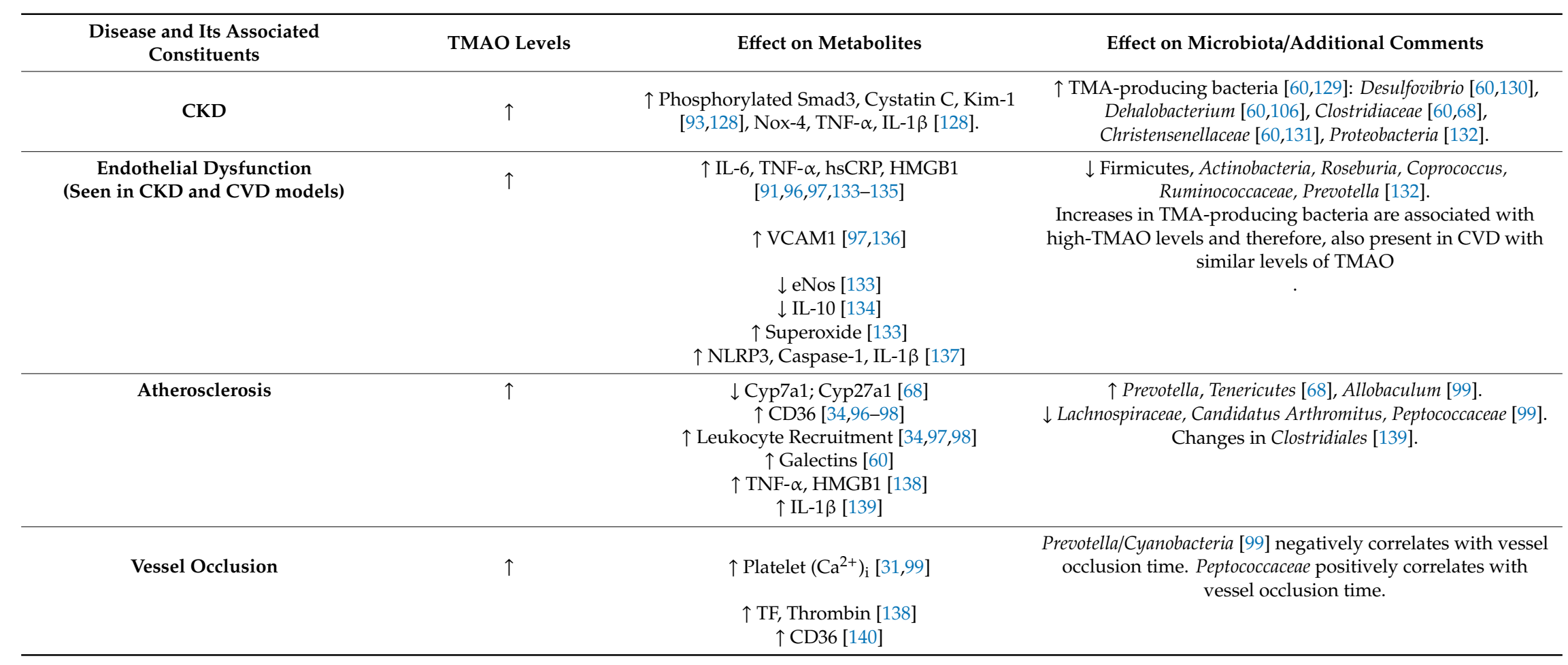


Table 2. Cont.

\begin{tabular}{|c|c|c|c|}
\hline $\begin{array}{c}\text { Disease and Its Associated } \\
\text { Constituents }\end{array}$ & TMAO Levels & Effect on Metabolites & Effect on Microbiota/Additional Comments \\
\hline MCD-Induced NASH & $\downarrow$ & $\begin{array}{c}\uparrow \text { PV1 }[112,113] \\
\downarrow \text { ZO-1 }[64,109,111,114] \\
\downarrow \text { Phosphatidyl choline/Triglyceride in LDLs } \\
{[116-118]} \\
\uparrow \text { Caspase-2 [116] } \\
\uparrow \text { TGF } \beta, \alpha \text { SMA, COL1A1, CRP2 [141,142] } \\
\uparrow \text { NLRP3, Caspase-1 }[116,118,121,141,143] \\
\uparrow \text { IL-18, IL-1 } \beta[119,141,142,144-146]\end{array}$ & $\begin{array}{c}\downarrow \text { Verrucomicrobia, Actinobacteria, Proteobacteria, } \\
\text { Bifidobacteriaceae [64], Lactobacilli [65,110], Akkermansia [65]. } \\
\uparrow \text { Lachnospiraceae, Barnesiella, Allobaculum [110,118], } \\
\text { Ruminococus [65,147], Bacteriodetes [64,147], Tenericutes, } \\
\text { Desulfovibrio, Enterobacteriaceae [64], Firmicutes, } \\
\text { Helicobacteraceae [64,118]. } \\
\text { Allobaculum negatively correlated with ZO-1 [118]. }\end{array}$ \\
\hline IBD & $\downarrow$ & $\begin{array}{c}\text { NLRP3 changes as detailed under NASH } \\
\text { above } \\
\downarrow \text { ATG16L1, LC3-II, P62 [148] }\end{array}$ & $\begin{array}{c}\uparrow \text { Firmicutes, Proteobacteria, Verrucomicrobia, Fusobacteria [149] } \\
\qquad \text { Bacteriodetes, Cyanobacteria [149]. }\end{array}$ \\
\hline
\end{tabular}




\section{Potential Therapies in Choline-Related Diseases}

Data from associative and mechanistic studies draw a strong link between dysbiosis and pathobiotic bacteria in the gut, the microbiota-dependent production of TMAO, and an increased risk of cardiometabolic and gastrointestinal disorders [98,113,150-153]. Since many of those disorders lack effective treatments, the gut microbiota has emerged as an attractive therapeutic target (see Table 3). Interventions designed to reverse dysbiosis and lower TMAO levels by (i) inducing alterations in the microbiota composition, which boosts the abundance of beneficial bacteria and reduces the TMAO production capacity, and (ii) directly disrupting the TMAO biosynthesis pathway are being developed as potential treatments (overviewed in Figure 5).

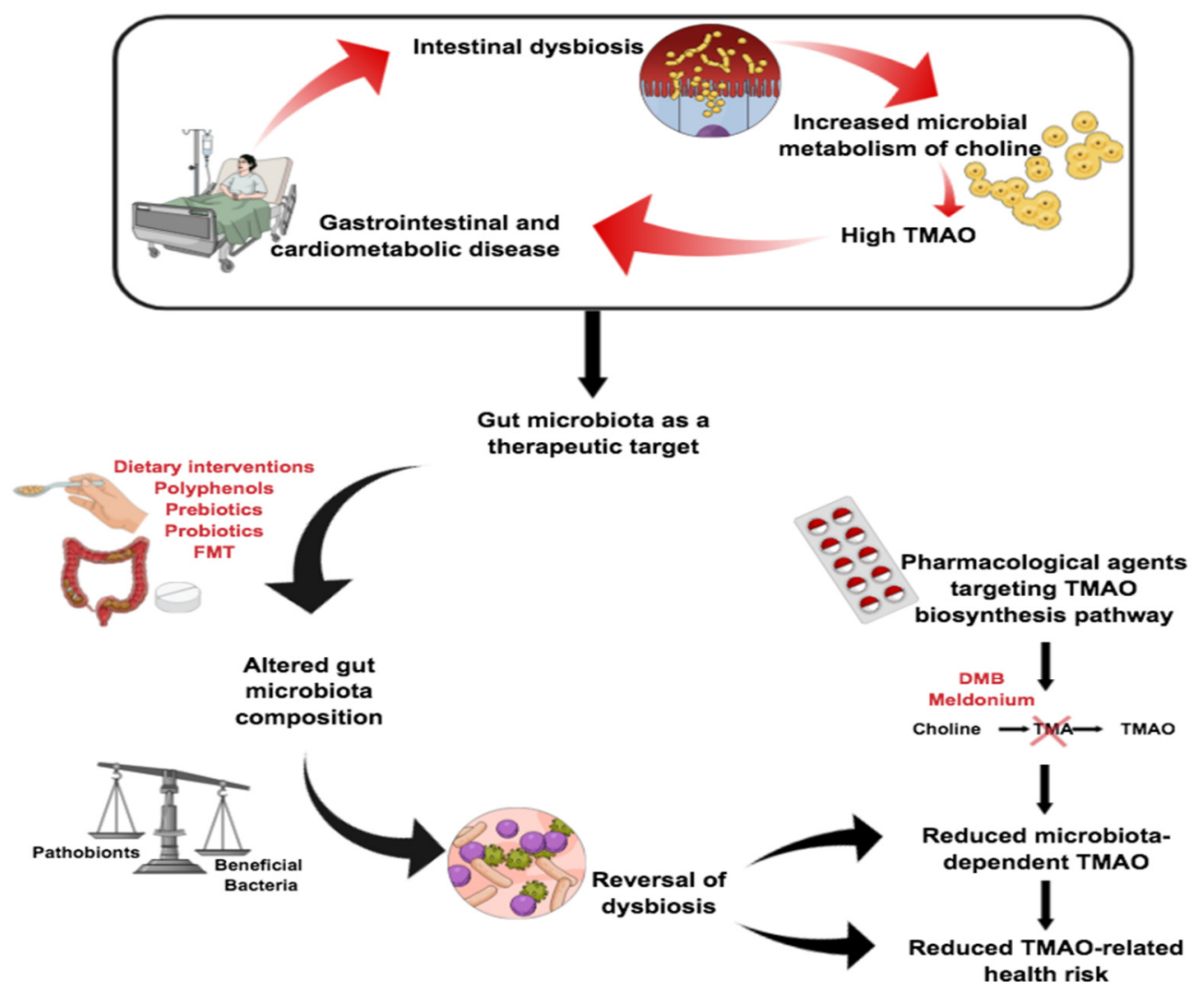

Figure 5. Overview of microbiota-targeting therapies for the treatment of gastrointestinal and cardiometabolic disorders Abbreviations: FMT, fecal microbiota treatment; DMB, 3,3-Dimethyl-1-Butanol.

As we have previously described, diet is an important lifestyle determinant of gut health. This makes dietary modification a potentially easy and relatively risk-free strategy for reducing TMAO-related health risks. Studies investigating the effect of diet on intestinal microbiota and TMAO levels have largely focused on the Mediterranean diet and veganism, both of which are rich in plant-derived polyphenols, high in fiber, and associated with multifaceted health benefits $[154,155]$. Epidemiological studies have reported an inverse correlation between habitual adherence to the Mediterranean diet and urinary [156] as well as plasma [157] TMAO levels in the Southern European population. However, six months of Mediterranean dietary intervention failed to reduce the fasting TMAO concentration in healthy North American volunteers at risk of colon cancer [158]. This discrepancy may be explained by population differences, which are known to affect the microbiota composition [159]. It also suggests that short-term interventions may be insufficient to induce re-modeling of intestinal microbiota shaped by years of the habitual consumption of a Western diet, known to cause dysbiosis and elevate TMAO levels in rodents [130]. 
Similarly, long-term adherence to a vegan diet is linked with a diminished capacity to biosynthesize TMAO from the dietary TMAO precursor L-carnitine [68], but studies comparing the baseline plasma concentration of TMAO between vegans and omnivores have yielded conflicting results $[68,160]$. This discrepancy may be explained by differences in inclusion criteria, with studies applying stricter criteria taking into account individuals' dietary history reporting more significant changes, suggesting an inverse correlation between years' spent vegan and TMAO levels. Notably, background diet was found to influence the meat consumption-induced TMAO concentration in a porcine model, with pigs fed high-fiber diets showing a significantly lower increase in TMAO levels compared to those kept on a high-fat Western-like background diet [161]. This emphasizes the modulatory effect of a habitual diet on short-term dietary intervention-related health outcomes.

'Functional foods' can exert beneficial effects on human health beyond their basic nutritional value. One example is given by prebiotics, defined as non-digestible food components selectively degraded by bacteria in the gut [162] that act to promote the growth of health-benefiting microbes. Non-digestible carbohydrates are the most commonly prescribed prebiotics, with a plethora of clinical data supporting their role in promoting microbial diversity [163]. Notably, prebiotic supplementation with soluble dietary fiber not only boosted the abundance of beneficial bacteria, but also significantly diminished TMA and TMAO metabolism (by $40.6 \%$ and $62.6 \%$, respectively) in mice fed a red meat rich diet. Moreover, this was accompanied by a marked reduction in weight, decrease in energy metabolism, and improved lipid and cholesterol markers [164]. Similarly, in humans, the consumption of an arabinoxylan-oligosaccharide-enriched prebiotic extract as part as an intervention trial in overweight adults was shown to increase the prevalence of Prevotella normally associated with non-Western diets low in processed foods [165]. Notably, the Prevotella abundance was also associated with an increase in short chain fatty acids and a rise in plasma phosphatidylcholine, indicative of a reduced availability of choline for TMA biosynthesis and a potential protective role in promoting metabolic health [165]. Likewise, long-term adherence to a diet enriched with dietary fiber was associated with a reduction in the TMAO concentration, accompanied by changes in the gut microbiota and improved metabolic health in obese children [166].

Polyphenols are phytochemicals produced as secondary metabolites in plants and constitute another class of chemical compounds of dietary origin with extra health benefits, known for their potent gut microbiota modulating properties. Notably, dietary supplementation with resveratrol (a stilbenoid polyphenol) increased the abundance of Lactobacillus, reduced the levels of TMAO and attenuated the atherosclerosis phenotype of $\mathrm{ApoE}^{-/-}$mice fed a high-choline diet [167]. Flavonoids present in oolong tea extracts and citrus peel were reported to have similar Lactobacillus-boosting effects, accompanied by a reduction in the carnitine-induced increase in TMAO plasma levels in mice [168]. A recent double-blind randomized trial evaluating the TMAO-reducing efficacy of Taurisolo, a polyphenolic-rich pomace extract, found that it induced a significant reduction in TMAO relative to the placebo $(63.6 \%$ vs. $0.54 \%)$ four weeks post-intervention [169]. However, additional mechanistic and human intervention studies are needed to further elucidate the relationship between polyphenols, microbiota-dependent TMAO levels, and human disease.

Another strategy for targeting TMAO is the use of probiotics (i.e., the ingestion of living microbes in adequate amounts that exert beneficial effects on human health) [170], with studies reporting promising microbiota re-modeling and TMAO-reducing effects in animal models. Eight weeks of dietary supplementation with Lactobacillus paracasei $\mathrm{F} 19$ protected rats from oxidative stress-induced liver damage by restoring the intestinal barrier and microbiota diversity [171], while gut colonization with M. smithii bacterial species was associated with a reduction in the TMAO concentration and attenuation of atherosclerosis in $\mathrm{ApoE}^{-/-}$mice [172]. Enterobacter aerogenes is another bacterial strain that has been shown to effectively reduce plasma TMAO and cecal TMAO levels by shifting the ratio of commensals and pathobionts in mice on a high-choline diet [173]. While the results are promising, it is important to apply caution when extrapolating findings from animal models into a clinical setting as the microbiome of rodents and humans are very different [174] and inter-personal differences in the 
microbiota composition resulting from the habitual diet and genetic make-up need to be considered, as previously explained.

A more recent approach to reversing dysbiosis is fecal microbiota transplantation (FMT), which is a type of fecal bacteriotherapy that involves complete replacement of the recipient's indigenous microbiome with healthy microbiota from a carefully selected donor. Despite positive results in pre-clinical studies, the method has yielded limited clinical success with antibiotic-resistant Clostridioides difficile infection being the only human condition for which FMT is currently approved [175]. However, it is currently unclear whether gut colonization is sufficient for clinical success in diseases beyond $C$. difficile infection. In this regard, a small FMT clinical study has shown to reverse gut dysbiosis but failed to induce remission in patients with chronic active ulcerative colitis [176]. Similarly, FMT in a double-blind randomized pilot study of 20 obese patients with metabolic syndrome elicited remodeling of the gut microbiota composition toward that of the vegan donor in some but not all recipients [160]. However, even in individuals that responded to the treatment, changes in the microbiota did not translate into a reduction in the TMAO production capacity nor alleviation of the atherosclerotic burden. In the future, precision-medicine-derived approaches could be adapted to transform FTM from an untargeted global microbiome replacement therapy into a more refined individual- and disease-specific intervention ensuring host-recipient compatibility by the application of standardized screening protocols and reliable donor selection criteria. However, this is contingent on developing an improved understanding of the causative relationship between individual bacterial strains and disease susceptibility.

Pharmacological agents designed to disrupt microbial metabolite biosynthesis cascades include a structural analogue of choline 3,3-Dimethyl-1-Butanol (DMB) and the anti-ischemic drug meldonium. DMB works to reduce TMAO levels and attenuate choline diet-induced atherosclerosis by inducing the non-lethal inhibition of TMA lyase in the gut, which is hypothesized to be associated with a reduced risk of resistance compared to antibiotic treatment, which causes considerably more selective pressure [177]. Despite its success in a pre-clinical model, the drug has never been tested in humans due to potential off-target adverse effects. Meldonium is a safer alternative, but clinical data suggest that it only inhibits TMAO produced from carnitine, and not choline [178].

Together, dietary interventions, the use of prebiotics/ probiotics, FMT, and pharmacotherapy represent an exciting potential avenue for the treatment of human diseases associated with dysbiosis and elevated TMAO levels. However, the success of microbiome-targeting therapies is contingent on developing an improved mechanistic understanding of interactions between the gut microbiota and disease pathogenesis. There is clearly a need for better designed randomized double-blind human trials with longer follow-up periods and bigger sample sizes. On the other hand, promoting lifestyle modifications that improve gut health is of significance as evidence suggests that long-term dietary habits and the state of the microbiome pre-treatment are important determinants of clinical success. 
Table 3. Dysbiosis, microbiota-dependent TMA production, and current treatments in choline-related diseases.

\begin{tabular}{|c|c|c|c|c|c|}
\hline Disorder. & Dysbiosis & TMA Production & Other Components & Therapy & Effects \\
\hline \multirow[t]{6}{*}{ CVD/atherosclerosis } & $\begin{array}{l}\text { Decreased microbial diversity; reduced } \\
\text { abundance of bacteria from } \\
\text { Lachnospiraceae family; correlation } \\
\text { between abundance of Candida, } \\
\text { Campylobacter, Shigella, and Yersinia } \\
\text { pathobions and heart failure } \\
\text { severity }[179,180]\end{array}$ & Increased [98] & $\begin{array}{c}\text { Increased plasma and } \\
\text { urine levels of TMAO; } \\
\text { increased expression of } \\
\text { FMAO3; } \\
\text { dietary choline-induced } \\
\text { formation of foam cells in } \\
\text { mice models }[98,181]\end{array}$ & Resveratrol & $\begin{array}{l}\text { Microbiota re-modeling; reduction in } \\
\text { TMAO levels [167]. }\end{array}$ \\
\hline & & & & SCFAs & $\begin{array}{c}\text { Vasodilation; decreased plasma TMA } \\
\text { levels and TMA:TMAO ratio; increased } \\
\text { microbial diversity [182]. }\end{array}$ \\
\hline & & & & DMB & $\begin{array}{l}\text { Reduction of TMAO and amelioration } \\
\text { of atherosclerotic burden in ApoE-/- } \\
\text { mice; suppression of TMA production } \\
\text { in-vitro [177]. }\end{array}$ \\
\hline & & & & $\begin{array}{l}\text { Probiotic } \\
\text { supplementation with } \\
\text { bacteria from } M \text {. } \\
\text { smithii/E. aerogenes } \\
\text { strains }\end{array}$ & $\begin{array}{c}\text { Reduced plasma/cecal levels of TMAO } \\
\text { and amelioration of atherosclerosis in } \\
\text { ApoE-/- mice; increased abundance of } \\
\text { beneficial bacteria }[172,173] .\end{array}$ \\
\hline & & & & Allicin & $\begin{array}{l}\text { Reduction in carnitine-induced } \\
\text { elevation of plasma TMAO levels in } \\
\text { mice, microbiota re-modeling [183]. }\end{array}$ \\
\hline & & & & Antibiotic therapy & $\begin{array}{l}\text { Plasma TMAO levels were greatly } \\
\text { reduced during antibiotic therapy and } \\
\text { quickly recovered after the treatment } \\
\text { was stopped [173]. }\end{array}$ \\
\hline $\begin{array}{l}\text { Inflammatory bowel } \\
\text { disease }\end{array}$ & $\begin{array}{l}\text { Broad gut microbiota dysbiosis; } \\
\text { reduced microbial diversity; decreased } \\
\text { abundance of Firmicutes and } \\
\text { Bacteroides; increased abundance of } \\
\text { Gammaproteobacteria }[86,184,185]\end{array}$ & Increased [186] & $\begin{array}{l}\text { Decreased levels of serum } \\
\text { choline; reduced TMAO } \\
\text { plasma levels in IBD } \\
\text { patients vs. control } \\
\text { population }[176,186]\end{array}$ & FMT & $\begin{array}{l}\text { Re-establishment of healthy gut } \\
\text { microbiota but failure to achieve } \\
\text { disease remission in chronic colitis } \\
\text { patients [176]. }\end{array}$ \\
\hline
\end{tabular}


Table 3. Cont.

\begin{tabular}{|c|c|c|c|c|c|}
\hline Disorder. & Dysbiosis & TMA Production & Other Components & Therapy & Effects \\
\hline \multirow[t]{3}{*}{ NAFLD } & $\begin{array}{c}\text { Increased abundance of } \\
\text { Erysipelotrichaceae, } \\
\text { reduced abundance of } \\
\text { Gammaproteobacteria; } \\
\text { reduced cecal abundance of lactic acid } \\
\text { bacteria Bifidobacterium and } \\
\text { Lactobacillus }[66,187]\end{array}$ & Increased [188] & $\begin{array}{c}\text { Low choline } \\
\text { bioavailability [66] }\end{array}$ & L-carnitine supplementation & $\begin{array}{l}\text { Decreased lipid accumulation and } \\
\text { oxidative stress injury, attenuation of } \\
\text { systemic inflammation and inhibition } \\
\text { of fibrosis progression in mice fed } \\
\text { choline deficient diet; increase in } \\
\text { TMAO levels in human } \\
\text { subjects }[189,190] .\end{array}$ \\
\hline & & & & $\begin{array}{l}\text { Probiotic supplementation } \\
\text { with } L \text {. paracasei F19 }\end{array}$ & $\begin{array}{c}\text { Re-establishment of microbiota } \\
\text { diversity; protection against oxidative } \\
\text { stress-induced liver damage in a rat } \\
\text { model [170] }\end{array}$ \\
\hline & & & & $\begin{array}{c}\text { Probiotic supplementation } \\
\text { with Lacticaseibacillus casei } \\
\text { strain Shirota }\end{array}$ & $\begin{array}{l}\text { Increased abundance of Bifidobacterium } \\
\text { and Lactobacillus in bacteria, alleviation } \\
\text { of NAFLD symptoms (including } \\
\text { altered expression of hepatic genes) in } \\
\text { MCD diet-induced mice model [191]. }\end{array}$ \\
\hline \multirow[t]{5}{*}{$\begin{array}{l}\text { Obesity/Metabolic } \\
\text { syndrome }\end{array}$} & $\begin{array}{l}\text { Decrease in fecal levels of Bacteroides } \\
\text { vulgatus; increased abundance of } \\
\text { Actinobacteria, Firmicutes, Proteobacteria; } \\
\text { reduced abundance of Bacteroides and } \\
\text { Oscillospira }[187,192]\end{array}$ & Increased [165] & $\begin{array}{l}\text { Increased TMAO } \\
\text { concentration in plasma } \\
\text { and urine [165] }\end{array}$ & FMT & $\begin{array}{l}\text { Microbiota re-modeling towards that of } \\
\text { the donor, but no reduction in TMAO } \\
\text { levels or improvement in metabolic } \\
\text { markers [160]. }\end{array}$ \\
\hline & & & & FMO3 enzyme inhibition & $\begin{array}{l}\text { Reduced conversion of TMA into } \\
\text { TMAO, improved lipid metabolism, } \\
\text { and reduction in inflammation [181]. }\end{array}$ \\
\hline & & & & $\begin{array}{c}\text { Prebiotics = dietary fiber } \\
\text { enriched diet }\end{array}$ & $\begin{array}{l}\text { Reduced TMAO levels, microbiota } \\
\text { re-modelling and improved metabolic } \\
\text { markers in obese children [166]. }\end{array}$ \\
\hline & & & & $\begin{array}{l}\text { Arabinoxylan-oligosaccharide } \\
\text { enriched prebiotic extract } \\
\text { supplementation }\end{array}$ & $\begin{array}{l}\text { Increased abundance of beneficial } \\
\text { Prevotella bacteria and reduced choline } \\
\text { availability for TMA synthesis in obese } \\
\text { adults [165]. }\end{array}$ \\
\hline & & & & $\begin{array}{l}\text { Prebiotic supplementation } \\
\text { with soluble dietary fiber }\end{array}$ & $\begin{array}{l}\text { Reduction in TMA and TMAO } \\
\text { metabolism (by } 40.6 \%) \text {, increased } \\
\text { abundance of beneficial bacteria, } \\
\text { decreased weight gain, improved lipid } \\
\text { and cholesterol markers in mice fed } \\
\text { with red meat [164]. }\end{array}$ \\
\hline
\end{tabular}

Abbreviations: CVD, cardiovascular disease; NAFLD, non-alcoholic fatty liver disease; SCFAs, short chain fatty acids; FMT, fecal microbiota transplantation; DMB, 3,3-dimethyl-1-butanol;

$\mathrm{MCD}$, methionine-choline-deficient. 


\section{Conclusions and Future Directions}

TMAO is a metabolite of dietary choline and is therefore dependent upon the consumption of precursors, host genetics, and gut microbial enzymatic activity. In this review, we described specific microbial enzymes involved in TMA production pathways as well as the microbes carrying the genes for these enzymes [135]. It is worth noting that the production of TMA/TMAO relies not only on gut microbiota, but also on host genetics, co-metabolism, and diet consumption. This gives rise to large inter-individual variability, raising the possibility that geographic differences in dietary patterns or gut microbial composition may affect the generalizability of results or require modifications to dietary intake [193].

However, important questions remain. Archaea has not received the same level of attention as bacteria, despite potentially being important in nutrient metabolism including TMA production, as supported by Fu et al. [194]. Regarding studies supporting the associations between TMAO and disease such as CVD, it is important to note that they have been mainly performed in people already with a disease, or at high risk of CVD, renal, or metabolic outcomes [195]. Therefore, it remains unknown as to whether this relationship is present in the general population. Moreover, TMAO levels rely on the consumption of dietary precursors, which is an association that should be further studied [193].

Another emerging field is the role of choline as an epigenetic modifier of the genome by changing the availability of methyl-donors such as S-adenosylmethionine (SAM). SAM synthesis depends on dietary choline ingestion and modulates neuronal gene expression and brain function. Therefore, the identification and implementation of effective nutritional strategies early in life could improve cognition and mental health [196].

Therefore, the study of the gut microbiome may significantly enhance our understanding of nutrient metabolism and specific pathways by which diet can influence health and cognition. This may facilitate the adoption of a individualized nutrition-based approach to target gut microbial structure and function as well as the potential to alter different metabolites such as TMAO production.

Author Contributions: All authors contributed equally to this review. All authors have read and agreed to the published version of the manuscript.

Funding: This work was supported by the Ministry of Science, Innovation and Universities (PSI2017-83893-R to J.L.A.) and the Ministry of Economy and Business (PSI2015-73111-EXP to J.L.A., PSI2017-90806-REDT to J.L.A. and AGL2017-83653R to M.G.) (Spain). S.A. was the recipient of a postdoctoral Juan de la Cierva Contract (Ministry of Science, Innovation and Universities, Ref. IJCI-2017-32156).

Acknowledgments: We would like to thank the Alzheimer's Research UK King's College London Network Center and the UK Dementia Research Institute (NA) for their technical and human support.

Conflicts of Interest: The authors declare no conflict of interest. The funders had no role in the design of the study; in the collection, analyses, or interpretation of data; in the writing of the manuscript, or in the decision to publish the review.

\section{References}

1. Wallace, T.C.; Blusztajn, J.K.; Caudill, M.A.; Klatt, K.C.; Natker, E.; Zeisel, S.H.; Zelman, K.M. The underconsumed and underappreciated essential nutrient. Nutr. Today 2018, 53, 240-253. [CrossRef] [PubMed]

2. Institute of Medicine. Dietary Reference Intakes: Thiamin, Riboflavin, Niacin, Vitamin B6, Folate, Vitamin B12, Pantothenic Acid, Biotin, and Choline; National Academies Press: Washington, DC, USA, 1998. [CrossRef]

3. Wiedeman, A.M.; Barr, S.I.; Green, T.J.; Xu, Z.; Innis, S.M.; Kitts, D.D. Dietary choline intake: Current state of knowledge across the life cycle. Nutrients 2018, 10, 1513. [CrossRef] [PubMed]

4. Vance, D.E.; Ridgway, N.D. The methylation of phosphatidylethanolamine. Prog. Lipid Res. 1988, 27, 61-79. [CrossRef]

5. Dalla Via, A.; Gargari, G.; Taverniti, V.; Rondini, G.; Velardi, I.; Gambaro, V.; Visconti, G.L.; De Vitis, V.; Gardana, C.; Ragg, E.; et al. Urinary TMAO levels are associated with the taxonomic composition of the gut microbiota and with the choline TMA-lyase gene (cutC) harbored by enterobacteriaceae. Nutrients 2020, 12, 62. [CrossRef] 
6. Borges, N.A.; Stenvinkel, P.; Bergman, P.; Qureshi, A.R.; Lindholm, B.; Moraes, C.; Stockler-Pinto, M.B.; Mafra, D. Effects of probiotic supplementation on trimethylamine-N-oxide plasma levels in hemodialysis patients: A pilot study. Probiotics Antimicrob. Proteins 2019, 11, 648-654. [CrossRef]

7. Patterson, Y.K.; Bhagwat, A.S.; Williams, R.J.; Howe, C.J.; Holden, M.J.; Zeisel, S.H.; Dacosta, K.A.; Mar, M.-H. USDA Database for The Choline Content of Common Foods, Release 2; Agricultural Research Service: Washington, DC, USA, 2008. [CrossRef]

8. Lewis, E.D.; Kosik, S.J.; Zhao, Y.Y.; Jacobs, R.L.; Curtis, J.M.; Field, C.J. Total choline and choline-containing moieties of commercially available pulses. Plant Foods Hum. Nutr. 2014, 69, 115-121. [CrossRef]

9. Zeisel, S.H. Dietary choline: Biochemistry, physiology, and pharmacology. Annu. Rev. Nutr. 1981, 1, 95-121. [CrossRef]

10. Zeisel, S.H. Nutrition in pregnancy: The Argument for Including a Source of Choline. Int. J. Womens Health 2013, 5, 193-199. [CrossRef]

11. Jiang, X.; Bar, H.Y.; Yan, J.; Jones, S.; Brannon, P.M.; West, A.A.; Perry, C.A.; Ganti, A.; Pressman, E.; Devapatla, S.; et al. A higher maternal choline intake among third-trimester pregnant women lowers placental and circulating concentrations of the antiangiogenic factor Fms-like tyrosine kinase-1 (sFLT1). FASEB J. 2013, 27, 1245-1253. [CrossRef]

12. Wu, B.T.F.; Dyer, R.A.; King, D.J.; Richardson, K.J.; Innis, S.M. Early second trimester maternal plasma choline and betaine are related to measures of early cognitive development in term infants. PLoS ONE 2012, 7, e43348. [CrossRef]

13. Zeisal, S.H.; da Costa, K.A. Choline: An essential nutrient for public health. Nutr. Rev. 2009, 67, 615-623. [CrossRef] [PubMed]

14. Leermakers, E.T.M.; Moreira, E.M.; Kiefte-de Jong, J.C.; Darweesh, S.K.L.; Visser, T.; Voortman, T.; Bautista, P.K.; Chowdhury, R.; Gorman, D.; Bramer, W.M.; et al. Effects of choline on health across the life course: A systematic review. Nutr. Rev. 2015, 73, 500-522. [CrossRef] [PubMed]

15. Zeisel, S.H.; Blusztajn, J.K. Choline and human nutrition. Annu. Rev. Nutr. 1994, 14, 269-296. [CrossRef] [PubMed]

16. Sarter, M.; Parikh, V. Choline transporters, cholinergic transmission and cognition. Nat. Rev. Neurosci. 2005, 6, 48-56. [CrossRef] [PubMed]

17. Garrow, T.A. Purification, kinetic properties, and cDNA cloning of mammalian betaine- homocysteine methyltransferase. J. Biol. Chem. 1996, 271, 22831-22838. [CrossRef] [PubMed]

18. Caudill, M.A. Pre-and postnatal health: Evidence of increased choline needs. J. Am. Diet. Assoc. 2010, 110, 1198-1206. [CrossRef]

19. Ikonomidou, C.; Bittigau, P.; Koch, C.; Genz, K.; Hoerster, F.; Felderho-Mueser, U.; Tenkova, T.; Dikranian, K.; Olney, J.W. Neurotransmitters and apoptosis in the developing brain. Biochem. Pharm. 2001, 62, 401-405. [CrossRef]

20. Bernhard, W.; Poets, C.F.; Franz, A.R. Choline and choline-related nutrients in regular and preterm infant growth. Eur. J. Nutr. 2019, 58, 931-945. [CrossRef]

21. Van Echten-Deckert, G.; Alam, S. Sphingolipid metabolism-an ambiguous regulator of autophagy in the brain. Biol. Chem. 2018, 399, 837-850. [CrossRef]

22. Zeisel, S.H.; Wishnok, J.S.; Blusztajn, J.K. Formation of methylamines from ingested choline and lecithin. J. Pharmacol. Exp. Ther. 1983, 225, 320-324.

23. Clemente, J.C.; Ursell, L.K.; Parfrey, L.W.; Knight, R. The impact of the gut microbiota on human health: An integrative view. Cell 2012, 148, 1258-1270. [CrossRef] [PubMed]

24. Milani, C.; Duranti, S.; Bottacini, F.; Casey, E.; Turroni, F.; Mahony, J.; Belzer, C.; Delgado Palacio, S.; Arboleya Montes, S.; Mancabelli, L.; et al. The first microbial colonizers of the human gut: Composition, activities, and health implications of the infant gut microbiota. Microbiol. Mol. Biol. Rev. 2017, 81. [CrossRef] [PubMed]

25. Salazar, N.; González, S.; Nogacka, A.M.; Rios-Covián, D.; Arboleya, S.; Gueimonde, M.; de los Reyes-Gavilán, C.G. Microbiome: Effects of Ageing and Diet. Curr. Issues Mol. Biol 2020, 36, 33-62. [CrossRef] [PubMed]

26. Levy, M.; Kolodziejczyk, A.A.; Thaiss, C.A.; Elinav, E. Dysbiosis and the immune system. Nat. Rev. Immunol. 2017, 17, 219-232. [CrossRef] [PubMed] 
27. Qin, J.; Li, R.; Raes, J.; Arumugam, M.; Burgdorf, K.S.; Manichanh, C.; Nielsen, T.; Pons, N.; Levenez, F.; Yamada, T.; et al. A human gut microbial gene catalogue established by metagenomic sequencing. Nature 2010, 464, 59-65. [CrossRef] [PubMed]

28. O'Hara, A.M.; Shanahan, F. The gut flora as a forgotten organ. EMBO Rep. 2006, 7, 688-693. [CrossRef] [PubMed]

29. Xiao, H.-W.; Cui, M.; Li, Y.; Dong, J.-L.; Zhang, S.-Q.; Zhu, C.-C.; Jiang, M.; Zhu, T.; Wang, B.; Wang, H.-C.; et al. Gut microbiota-derived indole 3-propionic acid protects against radiation toxicity via retaining acyl-CoA-binding protein. Microbiome 2020, 8, 69. [CrossRef] [PubMed]

30. Rowland, I.; Gibson, G.; Heinken, A.; Scott, K.; Swann, J.; Thiele, I.; Tuohy, K. Gut microbiota functions: Metabolism of nutrients and other food components. Eur. J. Nutr. 2018, 57, 1-24. [CrossRef]

31. Zhu, W.; Buffa, J.A.; Wang, Z.; Warrier, M.; Schugar, R.; Shih, D.M.; Gupta, N.; Gregory, J.C.; Org, E.; $\mathrm{Fu}, \mathrm{X}$; ; et al. Flavin monooxygenase 3, the host hepatic enzyme in the metaorganismal trimethylamine $\mathrm{N}$-oxide-generating pathway, modulates platelet responsiveness and thrombosis risk. J. Thromb. Haemost. 2018, 16, 1857-1872. [CrossRef]

32. Rath, S.; Rud, T.; Pieper, D.H.; Vital, M. Potential TMA-producing bacteria are ubiquitously found in mammalia. Front. Microbiol. 2020, 10, 2966. [CrossRef]

33. Treacy, E.P.; Akerman, B.R.; Chow, L.M.L.; Youil, R.; Bibeau, C.; Lin, J.; Cashman, J.R. Mutations of the flavin-containing monooxygenase gene (FMO3) cause trimethylaminuria, a defect in detoxication. Hum. Mol. Gen. 1998, 7, 839-845. [CrossRef] [PubMed]

34. Canyelles, M.; Tondo, M.; Cedó, L.; Farràs, M.; Escolà-Gil, J.C.; Blanco-Vaca, F. Trimethylamine N-oxide: A link among diet, gut microbiota, gene regulation of liver and intestine cholesterol homeostasis and HDL function. Int. J. Mol. Sci. 2018, 19, 3228. [CrossRef] [PubMed]

35. Chan, M.M.; Yang, X.; Wang, H.; Saaoud, F.; Sun, Y.; Fong, D. The microbial metabolite trimethylamine $\mathrm{N}$-oxide links vascular dysfunctions and the autoimmune disease rheumatoid arthritis. Nutrients 2019, 11, 1821. [CrossRef] [PubMed]

36. Wallace, T.C.; Blusztajn, J.K.; Caudill, M.A.; Klatt, K.C.; Zeisel, S.H. Choline: The neurocognitive essential nutrient of interest to obstetricians and gynaecologists. J. Diet. Suppl. 2019, 1-20. [CrossRef]

37. EFSA. Dietary reference values for choline. EFSA J. 2016, 14, 4484.

38. Zeisel, S.H.; Niculescu, M.D. Perinatal choline influences brain structure and function. Nutr. Rev. 2006, 64, 197-203. [CrossRef]

39. Bekdash, R.A. Choline, the brain and neurodegeneration: Insights from epigenetics. Front. Biosci. 2018, 23, 1113-1143. [CrossRef]

40. Rath, S.; Heidrich, B.; Pieper, D.H.; Vital, M. Uncovering the trimethylamine-producing bacteria of the human gut microbiota. Microbiome 2017, 5, 54. [CrossRef]

41. Romano, K.A.; Vivas, E.I.; Amador-Noguez, D.; Rey, F.E. Intestinal microbiota composition modulates choline bioavailability from diet and accumulation of the proatherogenic metabolite trimethylamine-N-oxide. MBio 2015, 6, e02481-14. [CrossRef]

42. Cho, C.E.; Taesuwan, S.; Malysheva, O.V.; Bender, E.; Tulchinsky, N.F.; Yan, J.; Caudill, M.A. Back cover: Trimethylamine-N-oxide (TMAO) response to animal source foods varies among healthy young men and is influenced by their gut microbiota composition: A randomized controlled trial. Mol. Nutr. Food Res. 2017, 61, 1600324. [CrossRef]

43. Hui, D.Y. Intestinal phospholipid and lysophospholipid metabolism in cardiometabolic disease. Curr. Opin. Lipidol. 2016, 27, 507-512. [CrossRef] [PubMed]

44. Falony, G.; Vieira-Silva, S.; Raes, J. Microbiology meets big data: The case of gut microbiota-derived trimethylamine. Annu. Rev. Microbiol. 2015, 69, 305-321. [CrossRef] [PubMed]

45. Shang, Y.; Wang, X.; Shang, X.; Zhang, H.; Liu, Z.; Yin, T.; Zhang, T. Repetitive transcranial magnetic stimulation effectively facilitates spatial cognition and synaptic plasticity associated with increasing the levels of BDNF and synaptic proteins in Wistar rats. Neurobiol. Learn. Mem. 2016, 134, 369-378. [CrossRef]

46. Martínez-del Campo, A.; Bodea, S.; Hamer, H.A.; Marks, J.A.; Haiser, H.J.; Turnbaugh, P.J.; Balskus, E.P. Characterization and detection of a widely distributed gene cluster that predicts anaerobic choline utilization by human gut bacteria. mBio 2015, 6, e00042-15. [CrossRef]

47. Zeisel, S.H.; Warrier, M. Trimethylamine N-Oxide, the microbiome, and heart and kidney disease. Annu. Rev. Nutr. 2017, 37, 157-181. [CrossRef] 
48. Zhu, Y.; Jameson, E.; Crosatti, M.; Schäfer, H.; Rajakumar, K.; Bugg, T.D.; Chen, Y. Carnitine metabolism to trimethylamine by an unusual Rieske-type oxygenase from human microbiota. Proc. Natl. Acad. Sci. USA 2014, 111, 4268-4273. [CrossRef]

49. Koeth, R.A.; Levison, B.S.; Culley, M.K.; Buffa, J.A.; Wang, Z.; Gregory, J.C.; Org, E.; Wu, Y.; Li, L.; Smith, J.D.; et al. $\gamma$-Butyrobetaine is a proatherogenic intermediate in gut microbial metabolism of L-carnitine to TMAO. Cell Metab. 2014, 20, 799-812. [CrossRef]

50. Wu, W.; Chen, C.; Liu, P.; Panyod, S.; Liao, B.-Y.; Chen, P.-C.; Kao, H.-L.; Kuo, H.-C.; Kuo, C.-H.; Chiu, T.H.T.; et al. Identification of TMAO-producer phenotype and host-diet-gut dysbiosis by carnitine challenge test in human and germ-free mice. Gut 2019, 68, 1439-1449. [CrossRef]

51. Craciun, S.; Marks, J.A.; Balskus, E.P. Characterization of choline trimethylamine-lyase expands the chemistry of glycyl radical enzymes. ACS Chem. Biol. 2014, 9, 1408-1413. [CrossRef]

52. Chhibber-Goel, J.; Gaur, A.; Singhal, V.; Parakh, N.; Bhargava, B.; Sharma, A. The complex metabolism of trimethylamine in humans: Endogenous and exogenous sources. Expert Rev. Mol. Med. 2016, 18, e8. [CrossRef]

53. Bennett., B.J.; de Aguiar Vallim, T.Q.; Wang, Z.; Shih, D.M.; Meng, Y.; Gregory, J.; Allayee, H.; Lee, R.; Graham, M.; Crooke, R.; et al. Trimethylamine-N-oxide, a metabolite associated with atherosclerosis, exhibits complex genetic and dietary regulation. Cell Metab. 2013, 17, 49-60. [CrossRef] [PubMed]

54. Hoyles, L.; Jiménez-Pranteda, M.L.; Chilloux, J.; Bria, F.; Myridakis, A.; Aranias, T.; Magnan, C.; Gibson, G.R.; Sanderson, J.D.; Nicholson, J.K.; et al. Metabolic retroconversion of trimethylamine N-oxide and the gut microbiota. Microbiome 2018, 6, 73. [CrossRef] [PubMed]

55. Fadhlaoui, K.; Arnal, M.E.; Martineau, M.; Camponova, P.; Ollivier, B.; O’Toole, P.W.; Brugère, J.F. Archaea, specific genetic traits, and development of improved bacterial live biotherapeutic products: Another face of next-generation probiotics. Appl. Microbiol. Biotechnol. 2020, 104, 4705-4716. [CrossRef] [PubMed]

56. Cotillard, A.; Kennedy, S.P.; Kong, L.C.; Prifti, E.; Pons, N.; Le Chatelier, E.; Gougis, S. Dietary intervention impact on gut microbial gene richness. Nature 2013, 500, 585-588. [CrossRef]

57. Arumugam, M.; Raes, J.; Pelletier, E.; Le Paslier, D.; Yamada, T.; Mende, D.R.; Fernandes, G.R.; Tap, J.; Bruls, T.; Batto, J.M.; et al. Enterotypes of the human gut microbiome. Nature 2011, 473, 174-180. [CrossRef]

58. Wu, G.D.; Chen, J.; Hoffmann, C.; Bittinger, K.; Chen, Y.Y.; Keilbaugh, S.A.; Bewtra, M.; Knights, D.; Walters, W.A.; Knight, R.; et al. Linking long-term dietary patterns with gut microbial enterotypes. Science 2011, 334, 105-108. [CrossRef]

59. Zeisel, S.H.; Mar, M.-H.; Howe, J.C.; Holden, J.M. Concentrations of choline-containing compounds and betaine in common foods. J. Nutr. 2003, 133, 1302-1307. [CrossRef]

60. Manor, O.; Zubair, N.; Conomos, M.P.; Xu, X.; Rohwer, J.E.; Krafft, C.E.; Lovejoy, J.C.; Magis, A.T. A multi-omic association study of trimethylamine N-oxide. Cell Rep. 2018, 24, 935-946. [CrossRef]

61. Tomova, A.; Bukovsky, I.; Rembert, E.; Yonas, W.; Alwarith, J.; Barnard, N.D.; Kahleova, H. The Effects of Vegetarian and Vegan Diets on Gut Microbiota. Front. Nutr. 2019, 6, 47. [CrossRef]

62. Guerrerio, A.L.; Colvin, R.M.; Schwartz, A.K.; Molleston, J.P.; Murray, K.F.; Diehl, A.; Mohan, P.; Schwimmer, J.B.; Lavine, J.E.; Torbenson, M.S.; et al. Choline intake in a large cohort of patients with nonalcoholic fatty liver. Am. J. Clin. Nutr. 2012, 95, 892-900. [CrossRef]

63. Yu, D.; Shu, X.-O.; Xiang, Y.-B.; Li, H.; Yang, G.; Gao, Y.-T.; Zheng, W.; Zhang, X. Higher dietary choline intake is associated with lower risk of nonalcoholic fatty liver in normal-weight Chinese women. J. Nutr. 2014, 144, 2034-2040. [CrossRef] [PubMed]

64. Ye, J.-Z.; Li, Y.-T.; Wu, W.-R.; Shi, D.; Fang, D.-Q.; Yang, L.-Y.; Bian, X.-Y.; Wu, J.-J.; Wang, Q.; Jiang, X.-W.; et al. Dynamic alterations in the gut microbiota and metabolome during the development of methionine-choline-deficient diet-induced non-alcoholic steatohepatitis. World J. Gastroenterol. 2018, 24, 2468-2481. [CrossRef] [PubMed]

65. Schneider, K.M.; Mohs, A.; Kilic, K.; Candels, L.S.; Elfers, C.; Bennek, E.; Schneider, L.B.; Heymann, F.; Gassler, N.; Penders, J.; et al. Intestinal Microbiota Protects against MCD-Diet Induced Steatohepatitis. Int. J. Mol. Sci. 2019, 20, 308. [CrossRef] [PubMed]

66. Spencer, M.D.; Hamp, T.J.; Reid, R.W.; Fischer, L.M.; Zeisel, S.H.; Fodor, A.A. Association between composition of the human gastrointestinal microbiome and development of fatty liver with choline deficiency. Gastroenterology 2011, 140, 976-986. [CrossRef] [PubMed] 
67. Ridlon, J.M.; Kang, D.J.; Hylemon, P.B.; Bajaj, J.S. Bile acids and the gut microbiome. Curr. Opin. Gastroenterol. 2014, 30, 332-338. [CrossRef]

68. Koeth, R.A.; Wang, Z.; Levison, B.S.; Buffa, J.A.; Org, E.; Sheehy, B.T.; Britt, E.B.; Fu, X.; Wu, Y.; Li, L.; et al. Intestinal microbiota metabolism of L-carnitine, a nutrient in red meat, promotes atherosclerosis. Nat. Med. 2013, 19, 576-585. [CrossRef]

69. Delgado, S.; Ruas-Madiedo, P.; Suárez, A.; Mayo, B. Interindividual differences in microbial counts and biochemical-associated variables in the feces of healthy Spanish adults. Dig. Dis Sci. 2006, 51, 737-743. [CrossRef]

70. Spor, A.; Koren, O.; Ley, R. Unravelling the effects of the environment and host genotype on the gut microbiome. Nat. Rev. Microbiol. 2011, 9, 279-290. [CrossRef]

71. Goodrich, J.K.; Waters, J.L.; Poole, A.C.; Sutter, J.L.; Koren, O.; Blekham, R.; Beaumont, M.; Van Treuren, W.; Knight, R.; Bell, J.T.; et al. Human genetics shape the gut microbiome. Cell 2014, 159, 789-799. [CrossRef]

72. Goodrich, J.K.; Davenport, E.R.; Beaumont, M.; Jackson, M.A.; Knight, R.; Ober, C.; Spector, T.D.; Bell, J.T.; Clark, A.G.; Ley, R.E. Genetic determinants of the gut microbiome in UK twins. Cell Host Microbe 2016, 19, 731-743. [CrossRef]

73. Blekhman, R.; Goodrich, J.K.; Huang, K.; Sun, Q.; Bukowski, R.; Bell, J.T.; Spector, T.D.; Keinan, A.; Ley, R.E.; Gevers, D.; et al. Host genetic variation impacts microbiome composition across human body sites. Genome Biol. 2015, 16, 191. [CrossRef] [PubMed]

74. Bonder, M.J.; Kurilshikov, A.; Tigchelaar, E.F.; Mujagic, Z.; Imhann, F.; Vila, A.V.; Deelan, P.; Vatanen, T.; Schirmer, M.; Smeekans, S.P.; et al. The effect of host genetics on the gut microbiome. Nat. Genet. 2016, 48, 1407-1412. [CrossRef] [PubMed]

75. Wang, J.; Thingholm, L.B.; Skiecevičiene, J.; Rausch, P.; Kummen, M.; Hov, J.R.; Degenhardt, F.; Heinsen, F.-A.; Rühlemann, M.C.; Szymczak, S.; et al. Genome-wide association analysis identifies variation in vitamin D receptor and other host factors influencing the gut microbiota. Nat. Genet. 2016, 48, 1396-1406. [CrossRef] [PubMed]

76. Li, D.; Achkar, J.-P.; Haritunians, T.; Jacobs, J.P.; Hui, K.Y.; D'Amato, M.; Brand, S.; Radford-Smith, G.; Halfvarson, J.; Niess, J.-H.; et al. A pleiotropic missense variant in SLC39A8 is associated with Crohn's disease and human gut microbiome composition. Gastroenterology 2016, 151, 724-732. [CrossRef] [PubMed]

77. Kashyap, P.C.; Marcobal, A.; Ursell, L.K.; Smits, S.A.; Sonnenburg, E.D.; Costello, E.K.; Higginbottom, S.K.; Domino, S.E.; Holmes, S.P.; Relman, D.A.; et al. Genetically dictated change in host mucus carbohydrate landscape exerts a diet-dependent effect on the gut microbiota. Proc. Natl. Acad. Sci. USA 2013, 110, 17059-17064. [CrossRef]

78. Tong, M.; McHardy, I.; Ruegger, P.; Goudarzi, M.; Kashyap, P.C.; Haritunians, T.; Li, X.; Graeber, T.G.; Schwager, E.; Huttenhower, C.; et al. Reprograming of gut microbiome energy metabolism by the FUT2 Crohn's disease risk polymorphism. ISME J. 2014, 8, 2193-2206. [CrossRef]

79. Juan-Mateu, J.; Rech, T.H.; Villate, O.; Lizarraga-Mollinedo, E.; Wendt, A.; Turatsinze, J.-V.; Brondani, L.A.; Nardelli, T.R.; Nogueira, T.C.; Esguerra, J.L.S.; et al. Neuron-enriched RNA-binding proteins regulate pancreatic beta cell function and survival. J. Biol. Chem. 2017, 292, 3466-3480. [CrossRef]

80. Davenport, E.R.; Cusanovich, D.A.; Michelini, K.; Barreiro, L.B.; Ober, C.; Gilad, Y. Genome-wide association studies of the human gut microbiota. PLoS ONE 2015, 10, e0140301. [CrossRef]

81. Org, E.; Parks, B.W.; Joo, J.W.J.; Emert, B.; Schwartzman, W.; Kang, E.Y.; Mehrabian, M.; Pan, C.; Knight, R.; Gunsalus, R.; et al. Genetic and environmental control of host-gut microbiota interactions. Genome Res. 2015, 25, 1558-1569. [CrossRef]

82. Benson, A.K.; Kelly, S.A.; Legge, R.; Ma, F.; Low, S.J.; Kim, J.; Zhang, M.; Oh, P.L.; Nehrenberg, D.; Hua, K.; et al. Individuality in gut microbiota composition is a complex polygenic trait shaped by multiple environmental and host genetic factors. Proc. Natl. Acad. Sci. USA 2010, 107, 18933-18938. [CrossRef]

83. Khachatryan, Z.A.; Ktsoyan, Z.A.; Manukyan, G.P.; Kelly, D.; Ghazaryan, K.A.; Aminov, R.I. Predominant role of host genetics in controlling the composition of gut microbiota. PLoS ONE 2008, 3, e3064. [CrossRef] [PubMed]

84. Zhang, C.; Zhang, M.; Wang, S.; Han, R.; Cao, Y.; Hua, W.; Mao, Y.; Zhang, X.; Pang, X.; Wei, C.; et al. Interactions between gut microbiota, host genetics and diet relevant to development of metabolic syndromes in mice. ISME J. 2010, 4, 312-313. [CrossRef] 
85. Wen, L.; Ley, R.E.; Volchkov, P.V.; Stranges, P.B.; Avanesyan, L.; Stonebraker, A.C.; Hu, C.; Wong, F.S.; Szot, G.L.; Bluestone, J.A.; et al. Innate immunity and intestinal microbiota in the development of Type 1 diabetes. Nature 2008, 455, 1109-1113. [CrossRef] [PubMed]

86. Frank, D.N.; Robertson, C.E.; Hamm, C.M.; Kpadeh, Z.; Zhang, T.; Chen, H.; Zhu, W.; Sartor, R.B.; Boedeker, E.C.; Harpaz, N.; et al. Disease phenotype and genotype are associated with shifts in intestinal-associated microbiota in inflammatory bowel diseases. Inflamm. Bowel Dis. 2011, 17, 179-184. [CrossRef]

87. De Palma, G.; Capilla, A.; Nadal, I.; Nova, E.; Pozo, T.; Varea, V.; Polanco, I.; Castillejo, G.; López, A.; Garrote, J.A.; et al. Interplay between human leukocyte antigen genes and the microbial colonization process of the newborn intestine. Curr. Issues Mol. Biol. 2010, 12, 1-10.

88. Salzman, N.H.; Hung, K.; Haribhai, D.; Chu, C.; Karlsson-Sjöberg, J.; Amir, E.; Teggatz, P.; Barman, M.; Hayward, M.; Eastwood, D.; et al. Enteric defensins are essential regulators of intestinal microbial ecology. Nat Immunol. 2010, 11, 76-83. [CrossRef]

89. Suzuki, K.; Meek, B.; Doi, Y.; Muramatsu, M.; Chiba, T.; Honjo, T.; Fagarasan, S. Aberrant expansion of segmented filamentous bacteria in IgA-deficient gut. Proc. Natl. Acad. Sci. USA 2004, 101, 1981-1986. [CrossRef]

90. Heianza, Y.; Ma, W.; DiDonato, J.A.; Sun, Q.; Rimm, E.B.; Hu, F.B.; Rexrode, K.M.; Manson, J.E.; Qi, L. Long-Term Changes in Gut Microbial Metabolite Trimethylamine N-Oxide and Coronary Heart Disease Risk. J. Am. Coll. Cardiol. 2020, 75, 763-772. [CrossRef]

91. Missailidis, C.; Hällqvist, J.; Qureshi, A.R.; Barany, P.; Heimbürger, O.; Lindholm, B.; Stenvinkel, P.; Bergman, P. Serum Trimethylamine- $N$-Oxide is Strongly Related to Renal Function and Predicts Outcome in Chronic Kidney Disease. PLoS ONE 2016, 11, e0141738. [CrossRef]

92. Stubbs, J.R.; House, J.A.; Ocque, A.J.; Zhang, S.; Johnson, C.; Kimber, C.; Schmidt, K.; Gupta, A.; Wetmore, J.B.; Nolin, T.D.; et al. Serum Trimethylamine-N-Oxide is Elevated in CKD and Correlates with Coronary Atherosclerosis Burden. J. Am. Soc. Nephrol. 2016, 27, 305-313. [CrossRef]

93. Tang, W.H.W.; Wang, Z.; Kennedy, D.; Wu, Y.; Buffa, J.; Agatisa-Boyle, B.; Li, X.S.; Levison, B.S.; Hazen, S.L. Gut Microbiota-Dependent Trimethylamine N-oxide (TMAO) Pathway Contributes to Both Development of Renal Insufficiency and Mortality Risk in Chronic Kidney Disease. Circ. Res. 2015, 116, 448-455. [CrossRef] [PubMed]

94. Qu, X.; Li, X.; Zheng, Y.; Ren, Y.; Puelles, V.G.; Caruana, G.; Nikolic-Paterson, D.-J.; Li, J. Regulation of renal fibrosis by Smad3 Thr388 phosphorylation. Am. J. Pathol. 2014, 184, 944-952. [CrossRef] [PubMed]

95. Zhao, Y.; Vanhoutte, P.M.; Leung, S.W.S. Vascular nitric oxide: Beyond eNOS. J. Pharmacol. Sci. 2015, 129, 83-94. [CrossRef] [PubMed]

96. Geng, J.; Yang, C.; Wang, B.; Zhang, X.; Hu, T.; Gu, Y.; Li, J. Trimethylamine N-oxide promotes atherosclerosis via CD36-dependent MAPK/JNK pathway. Biomed. Pharmacother. 2018, 97, 941-947. [CrossRef]

97. Seldin, M.M.; Meng, Y.; Qi, H.; Zhu, W.F.; Wang, Z.; Hazen, S.L.; Lusis, A.J.; Shih, D.M. Trimethylamine N-Oxide Promotes Vascular Inflammation through Signalling of Mitogen-Activated Protein Kinase and Nuclear Factor-kB. J. Am. Heart Assoc. 2016, 5, e002767. [CrossRef]

98. Wang, Z.; Klipfell, E.; Bennett, B.J.; Koeth, R.; Levison, B.S.; Dugar, B.; Feldstein, A.E.; Britt, E.B.; Fu, X.; Chung, Y.M.; et al. Gut flora metabolism of phosphatidylcholine promotes cardiovascular disease. Nature 2011, 472, 57-65. [CrossRef]

99. Zhu, W.; Gregory, J.C.; Org, E.; Buffa, J.; Gupta, N.; Wang, Z.; Li, L.; Fu, X.; Wu, Y.; Mehrabian, M.; et al. Gut microbial metabolite TMAO enhances platelet hyperactivity and thrombosis risk. Cell 2016, 165, 111-124. [CrossRef]

100. Romano, K.A.; Martinez-del Campo, A.; Kasahara, K.; Chittim, C.L.; Vivas, E.I.; Amador-Noguez, D.; Balskus, E.P.; Rey, F.E. Metabolic, Epigenetic, and Transgenerational Effects of Gut Bacterial Choline Consumption. Cell Host Microbe 2017, 22, 279-290. [CrossRef]

101. Mafra, D.; Esgalhado, M.; Borges, N.A.; Cardozo, L.F.M.F.; Stockler-Pinto, M.B.; Craven, H.; Buchanan, S.J.; Lindholm, B.; Stenvinkel, P.; Shiels, P.G. Methyl Donor Nutrients in Chronic Kidney Disease: Impact on the Epigenetic Landscape. J. Nutr. 2019, 149, 372-380. [CrossRef]

102. Zinellu, A.; Sotgia, S.; Sotgiu, E.; Assaretti, S.; Baralla, A.; Mangoni, A.A.; Satta, A.E.; Carru, C. Cholesterol Lowering Treatment Restores Blood Global DNA Methylation in Chronic Kidney Disease (CKD) Patients. Nutr. Metab. Cardiovasc. Dis. 2017, 27, 822-829. [CrossRef] 
103. Castro, R.; Rivera, I.; Struys, E.A.; Jansen, E.E.W.; Ravasco, P.; Camilo, M.E.; Blom, H.J.; Jakobs, C.; Tavares de Almeida, I. Increased Homocysteine and S-Adenosylhomocysteine Concentrations and DNA Hypomethylation in Vascular Disease. Clin. Chem. 2003, 49, 1292-1296. [CrossRef] [PubMed]

104. Chu, A.Y.; Tin, A.; Schlosser, P.; Ko, Y.-A.; Qiu, C.; Yao, C.; Joehanes, R.; Grams, M.E.; Liang, L.; Gluck, C.A.; et al. Epigenome-wide Association Studies Identify DNA Methylation Associated with Kidney Function. Nat. Commun. 2017, 8, 1286. [CrossRef] [PubMed]

105. Stenvinkel, P.; Karimi, M.; Johansson, S.; Axelsson, J.; Suliman, M.; Lindholm, B.; Heimbürger, O.; Barany, P.; Alvestrand, A.; Nordfors, L.; et al. Impact of Inflammation on Epigenetic DNA Methylation-A Novel Risk Factor for Cardiovascular Disease. J. Intern. Med. 2007, 261, 488-499. [CrossRef] [PubMed]

106. Dam, K.; Füchtemeier, M.; Farr, T.D.; Boehm-Sturm, P.; Foddis, M.; Dirnagl, U.; Malysheva, O.; Caudill, M.A.; Jadavji, N.M. Increased Homocysteine Levels Impair Reference Memory and Reduce Cortical Levels of Acetylcholine in a Mouse Model of Vascular Cognitive Impairment. Behav. Brain. Res. 2017, 321, 201-208. [CrossRef]

107. Zeisel, S.H. Gene Response Elements, Genetic Polymorphisms and Epigenetics Influence the Human Dietary Requirement for Choline. IUBMB Life 2007, 59, 380-387. [CrossRef]

108. Younossi, Z.M.; Koenig, A.B.; Abdelatif, D.; Fazel, Y.; Henry, L.; Wymer, M. Global Epidemiology of Nonalcoholic Fatty Liver disease -Meta-analytic Assessment of Prevalence, Incidence, and Outcomes. Hepatology 2016, 64, 73-84. [CrossRef] [PubMed]

109. Sawada, Y.; Kawaratani, H.; Kubo, T.; Fujinaga, Y.; Furukawa, M.; Saikawa, S.; Sato, S.; Seki, K.; Takaya, H.; Okura, Y.; et al. Combining probiotics and an angiotensin-II type 1 receptor blocker has beneficial effects on hepatic fibrogenesis in a rat model of non-alcoholic steatohepatitis. Hepatol. Res. 2019, 49, $284-295$. [CrossRef]

110. Le Roy, T.; Llopis, M.; Lepage, P.; Bruneau, A.; Rabot, S.; Bevilacqua, C.; Martin, P.; Philippe, C.; Walker, F.; Bado, A.; et al. Intestinal microbiota determines development of non-alcoholic fatty liver disease in mice. Gut 2013, 62, 1787-1794. [CrossRef]

111. Luther, J.; Garber, J.J.; Khalili, H.; Dave, M.; Bale, S.S.; Jindal, R.; Motola, D.L.; Luther, S.; Bohr, S.; Jeoung, S.W.; et al. Hepatic Injury in Nonalcoholic Steatohepatitis Contributes to Altered Intestinal Permeability. Cell Mol. Gastroenterol. Hepatol. 2015, 1, 222-232.e2. [CrossRef]

112. Mouries, J.; Brescia, P.; Silvestri, A.; Spadoni, I.; Sorribas, M.; Wiest, R.; Mileti, E.; Galbiati, M.; Invernizzi, P.; Adorini, L.; et al. Microbiota-driven gut vascular barrier disruption is a pre-requisite for non-alcoholic steatohepatitis development. J. Hepatol. 2019, 71, 1216-1228. [CrossRef]

113. Spadoni, I.; Zagato, E.; Bertocchi, A.; Paolinelli, R.; Hot, E.; Di Sabatino, A.; Caprioli, F.; Bottiglieri, L.; Oldani, A.; Viale, G.; et al. A gut-vascular barrier controls the systemic dissemination of bacteria. Science 2015, 350, 830-834. [CrossRef] [PubMed]

114. Miele, L.; Valenza, V.; La Torre, G.; Montalto, M.; Cammarota, G.; Ricci, R.; Masciana, R.; Forgione, A.; Gabrieli, M.L.; Perotti, G.; et al. Increased intestinal permeability and tight junction alterations in nonalcoholic fatty liver disease. Hepatol. 2009, 49, 1877-1887. [CrossRef] [PubMed]

115. Ibrahim, S.H.; Kohli, R.; Gores, G.J. Mechanisms of lipotoxicity in NAFLD and clinical implications. J. Pediatr. Gastroenterol. Nutr. 2011, 53, 131-140. [CrossRef]

116. Machado, M.V.; Michelotti, G.A.; Xie, G.; Pereira de Almeida, T.; Boursier, J.; Bohnic, B.; Guy, C.D.; Diehl, A.M. Mouse Models of Diet-Induced Nonalcoholic Steatohepatitis Reproduce the Heterogeneity of the Human Disease. PLoS ONE 2015, 10, e0127991. [CrossRef]

117. Yao, Z.M.; Vance, D.E. Reduction in VLDL, but not HDL, in plasma of rats deficient in choline. Biochem. Cell Biol. 1990, 68, 552-558. [CrossRef] [PubMed]

118. Mingnuan, H.; Zhang, T.; Gu, W.; Yang, X.; Zhao, R.; Yu, J. 2,3,4,5'-tetrahydroxy-stilbene-2-O- $\beta$-D-glucoside attenuates methionine and choline-deficient diet-induced non-alcoholic fatty liver disease. Exp. Ther. Med. 2018, 16, 1087-1094. [CrossRef]

119. Csak, T.; Ganz, M.; Pespisa, J.; Kodys, K.; Dolganiuc, A.; Szabo, G. Fatty Acid and Endotoxin Activate Inflammasomes in Mouse Hepatocytes that Release Danger Signals to Stimulate Immune Cells. Hepatol. 2011, 54, 133-144. [CrossRef]

120. Krenkel, O.; Puengel, T.; Govaere, O.; Abdallah, A.T.; Mossanen, J.C.; Kohlhepp, M.; Liepelt, A.; Lefebvre, E.; Luedde, T.; Hellerbrand, C.; et al. Therapeutic inhibition of inflammatory monocyte recruitment reduces steatohepatitis and liver fibrosis. Hepatol. 2018, 67, 1270-1283. [CrossRef] [PubMed] 
121. Neudecker, V.; Haneklaus, M.; Jensen, O.; Khailova, L.; Masterson, J.C.; Tye, H.; Biette, K.; Jedlicka, P.; Brodsky, K.S.; Gerich, M.E.; et al. Myeloid-derived miR-223 Regulates Intestinal Inflammation via Repression of the NLRP3 Inflammasome. J. Exp. Med. 2017, 214, 1737-1752. [CrossRef]

122. Mao, L.; Kitani, A.; Strober, W.; Fuss, I.J. The role of NLRP3 and IL-1 $\beta$ in the Pathogenesis of Inflammatory Bowel Disease. Front. Immunol. 2018, 9, 2566. [CrossRef] [PubMed]

123. Janeiro, M.H.; Ramirez, M.J.; Milagro, F.I.; Martinez, J.A.; Solas, M. Implication of Trimethylamine N-Oxide (TMAO) in Disease: Potential Biomarker or New Therapeutic Target. Nutrients 2018, 10, 1398. [CrossRef] [PubMed]

124. Papandreou, C.; More, M.; Bellamine, A. Trimethylamine N-Oxide in Relation to Cardiometabolic Health-Cause or Effect? Nutrients 2020, 12, 1330. [CrossRef] [PubMed]

125. Jaworska, K.; Hering, D.; Mosieniak, G.; Bielak-Zmijewska, A.; Pilz, M.; Konwerski, M.; Gasecka, A.; Kaplon-Cieślicka, A.; Filipiak, K.; Sikora, E.; et al. TMA, A Forgotten Uremic Toxin, but Not TMAO, Is Involved in Cardiovascular Pathology. Toxins 2019, 11, 490. [CrossRef] [PubMed]

126. Pignanelli, M.; Just, C.; Bogiatzi, C.; Dinculescu, V.; Gloor, G.B.; Allen-Vercoe, E.; Reid, G.; Urquhart, B.L.; Ruetz, K.N.; Velenosi, T.J.; et al. Mediterranean Diet Score: Associations with Metabolic Products of the Intestinal Microbiome, Carotid Plaque Burden, and Renal Function. Nutrients 2018, 10, 779. [CrossRef]

127. Wu, Q.; Zhao, Y.; Zhang, X.; Yang, X. A Faster and Simpler UPLC-MS/MS Method for the Simultaneous Determination of Trimethylamine N-oxide, Trimethylamine and Dimethylamine in Different Types of Biological Samples. Food Funct. 2019, 10, 6484-6491. [CrossRef]

128. Sun, G.; Yin, Z.; Liu, N.; Bian, X.; Yu, R.; Su, X.; Zhang, B.; Wang, Y. Gut Microbial Metabolite TMAO Contributes to Renal Dysfunction in a Mouse Model of Diet-Induced Obesity. Biochem. Biophys. Res. Commun. 2017, 493, 964-970. [CrossRef]

129. Li, T.; Gua, C.; Wu, B.; Chen, Y. Increased Circulating trimethylamine N-oxide contributes to endothelial dysfunction in a rat model of chronic kidney disease. Biochem. Biophys. Res. Commun. 2018, 495, 2071-2077. [CrossRef]

130. Chen, K.; Zheng, X.; Feng, M.; Li, D.; Zhang, H. Gut Microbiota-Dependent Metabolite Trimethylamine N-Oxide Contributes to Cardiac Dysfunction in Western Diet-Induced Obese Mice. Front. Physiol. 2017, 8, 139. [CrossRef]

131. Singh, G.B.; Zhang, Y.; Boini, K.M.; Koka, S. High Mobility Group Box 1 Mediates TMAO-Induced Endothelial Dysfunction. Int. J. Mol. Sci. 2019, 20, 3570. [CrossRef]

132. Ma, G.; Pan, B.; Chen, Y.; Guo, C.; Zhao, M.; Zheng, L.; Chen, B. Trimethylamine N-Oxide in Atherogenesis: Impairing Endothelial Self-Repair Capacity and Enhancing Monocyte Adhesion. Biosci. Rep. 2017, 37, BSR20160244. [CrossRef]

133. Bioni, K.M.; Hussain, T.; Li, P.-L.; Koka, S. Trimethylamine-N-Oxide Instigates NLRP3 Inflammasome Activation and Endothelial Dysfunction. Cell. Physiol. Biochem. 2017, 44, 152-162. [CrossRef] [PubMed]

134. Al-Obaide, M.A.I.; Singh, R.; Datta, P.; Rewers-Felkins, K.A.; Salguero, M.V.; Al-Obaidi, I.; Rao Kottapalli, K.; Vasylyeva, T.L. Gut Microbiota-Dependent Trimethylamine- $N$-Oxide and Serum Biomarkers in Patients with T2DM and Advanced CKD. J. Clin. Med. 2017, 6, 86. [CrossRef] [PubMed]

135. Craciun, S.; Balskus, E.P. Microbial Conversion of Choline to Trimethylamine Requires a Glycyl Radical Enzyme. Proc. Natl. Acad. Sci. USA 2012, 109, 21307-21312. [CrossRef] [PubMed]

136. Bell, J.S. Effects of a Flavonoid-Rich Diet on Gut Microbiota Composition and Production of Trimethylamine in Human Subjects. Master's Thesis, Utah State University, Logan, UT, USA, May 2016.

137. Xu, K.Y.; Xia, G.H.; Lu, J.Q.; Chen, M.X.; Zhen, X.; Wang, S.; You, C.; Nie, J.; Zhou, H.W.; Yin, J. Impaired Renal Function and Dysbiosis of Gut Microbiota Contribute to Increased Trimethylamine-N-Oxide in Chronic Kidney Disease Patients. Sci. Rep. 2017, 7, 1445. [CrossRef]

138. Cheng, X.; Qiu, X.; Liu, Y.; Yuan, C.; Yang, X. Trimethylamine N-Oxide Promotes Tissue Factor Expression and Activity in Vascular Endothelial Cells: A New Link Between Trimethylamine N-Oxide and Atherosclerotic Thrombosis. Thromb. Res. 2019, 177, 110-116. [CrossRef]

139. Jonsson, A.L.; Caesar, R.; Akrami, R.; Reinhardt, C.; Hållenius, F.F.; Borén, J.; Bäckhed, F. Impact of gut microbiota and diet on the development of atherosclerosis in ApoE-/- mice. Arterioscler. Thromb. Vasc. Biol. 2018, 38, 2318-2326. [CrossRef]

140. Podrez, E.A.; Byzova, T.V.; Febbraio, M.; Salomon, R.G.; Ma, Y.; Valiyaveettil, M.; Poliakov, E.; Sun, M.; Finton, P.J.; Curtis, B.R.; et al. Platelet CD36 Links Hyperlipidemia, Oxidant Stress and a Prothrombotic Phenotype. Nat. Med. 2007, 13, 1086-1095. [CrossRef] 
141. Wree, A.; McGeough, M.D.; Peña, C.A.; Schlattjan, M.; Li, H.; Inzaugarat, M.E.; Messer, K.; Canbay, A.; Hoffman, H.M.; Feldstein, A.E. NLRP3 Inflammasome Activation is Required for Fibrosis Development in NAFLD. J. Mol. Med. 2014, 92, 1069-1082. [CrossRef]

142. Dixon, L.; Berk, M.; Thapaliya, S.; Papouchado, B.G.; Feldstein, A.E. Caspase 1-Mediated Regulation of Fibrogenesis in Diet-Induced Steatohepatitis. Lab. Investig. 2012, 92, 713-723. [CrossRef]

143. Bauernfeind, F.; Rieger, A.; Schildberg, F.A.; Knolle, P.A.; Schmid-Burgk, J.L.; Hornung, V. NLRP3 Inflammasome Activity is Negatively Controlled by miR-223. J. Immunol. 2012, 189, 4175-4181. [CrossRef]

144. Bergsbaken, T.; Fink, S.L.; Cookson, B.T. Pyroptosis: Host Cell Death and Inflammation. Nat. Rev. Microbiol. 2009, 7, 99-109. [CrossRef] [PubMed]

145. Strowig, T.; Henao-Mejia, J.; Elinav, E.; Flavell, R. Inflammasomes in Health and Disease. Nature 2012, 481, 278-286. [CrossRef] [PubMed]

146. Coccia, M.; Harrison, O.J.; Schiering, C.; Asquith, M.J.; Becher, B.; Powrie, F.; Maloy, K.J. IL-1 $\beta$ Mediates Chronic Intestinal Inflammation by Promoting the Accumulation of IL-17A Secreting Innate Lymphoid Cells and CD4 ${ }^{+}$Th17 Cells. J. Exp. Med. 2012, 209, 1595-1609. [CrossRef] [PubMed]

147. Boursier, J.; Mueller, O.; Barrett, M.; Machado, M.; Fizanne, L.; Araujo-Perez, F.; Guy, C.D.; Seed, P.C.; Rawls, J.F.; David, L.A.; et al. The Severity of Nonalcoholic Fatty Liver Disease is Associated with Gut Dysbiosis and Shift in the Metabolic Function of the Gut Microbiota. Hepatology 2016, 63, 764-775. [CrossRef]

148. Yue, C.; Yang, X.; Li, J.; Chen, X.; Zhao, X.; Chen, Y.; Wen, Y. Trimethylamine N-Oxide Prime NLRP3 Inflammasome via Inhibiting ATG16L1-Induced Autophagy in Colonic Epithelial Cells. Biochem. Biophys. Res. Commun. 2017, 490, 541-551. [CrossRef]

149. Santoru, M.L.; Piras, C.; Murgia, A.; Palmas, V.; Camboni, T.; Liggi, S.; Ibba, I.; Lai, M.A.; Orrú, S.; Blois, S.; et al. Cross Sectional Evaluation of the Gut-Microbiome Metabolome Axis in an Italian Cohort of IBD Patients. Sci. Rep. 2017, 7, 9523. [CrossRef]

150. Gregory, J.C.; Buffa, J.A.; Org, E.; Wang, Z.; Levison, B.S.; Zhu, W.; Wagner, M.A.; Bennett, B.J.; Li, L.; DiDonato, J.A.; et al. Transmission of atherosclerosis susceptibility with gut microbial transplantation. J. Biol. Chem. 2015, 290, 5647-5660. [CrossRef]

151. Eyupoglu, N.D.; Guzelce, E.C.; Acikgoz, A.; Uyanik, E.; Bjørndal, B.; Berge, R.K.; Svardal, A.; Okan, B. Circulating gut microbiota metabolite trimethylamine $\mathrm{N}$-oxide and oral contraceptive use in polycystic ovary syndrome. Clin. Endocrinol. 2019, 91, 810-815. [CrossRef]

152. Wang, Z.; Tang, W.H.W.; Buffa, J.A.; Fu, X.; Britt, E.B.; Koeth, R.A.; Levison, B.S.; Fan, Y.; Wu, Y.; Hazen, S.L. Prognostic value of choline and betaine depends on intestinal microbiota-generated metabolite trimethylamine-N-oxide. Eur. Heart J. 2014, 35, 904-910. [CrossRef]

153. Wilson, A.; Teft, W.A.; Morse, B.L.; Choi, Y.H.; Woolsey, S.; DeGorter, M.K.; Hegele, R.A.; Tirona, R.G.; Kim, R.B. Trimethylamine-N-oxide: A Novel Biomarker for the Identification of Inflammatory Bowel Disease. Dig. Dis. Sci. 2015, 60, 3620-3630. [CrossRef]

154. Le, L.T.; Sabate, J. Beyond meatless, the health effects of vegan diets: Findings from the Adventist cohorts. Nutrients 2014, 6, 2131-2147. [CrossRef] [PubMed]

155. Battino, M.; Forbes-Hernandez, T.Y.; Gasparrini, M.; Afrin, S.; Cianciosi, D.; Zhang, J.; Manna, P.P.; Reboredo-Rodriguez, P.; Varela Lopez, A.; Quiles, J.L.; et al. Relevance of functional foods in the Mediterranean diet: The role of olive oil, berries and honey in the prevention of cancer and cardiovascular diseases. Crit. Rev. Food. Sci. Nutr. 2019, 59, 893-920. [CrossRef] [PubMed]

156. De Filippis, F.; Pellegrini, N.; Vannini, L.; Jeffery, I.B.; La Storia, A.; Laghi, L.; Serrazanetti, D.I.; Di Cagno, R.; Ferrocino, I.; Lazzi, C. High-level adherence to a Mediterranean diet beneficially impacts the gut microbiota and associated metabolome. Gut 2016, 65, 1812-1821. [CrossRef]

157. Barrea, L.; Annunziata, G.; Muscogiuri, G.; Laudisio, D.; Di Somma, C.; Maisto, M.; Tenore, G.C.; Colao, A.; Savastano, S. Trimethylamine N-oxide, Mediterranean diet, and nutrition in healthy, normal-weight adults: Also a matter of sex? Nutrition 2019, 62, 7-17. [CrossRef] [PubMed]

158. Griffin, L.E.; Djuric, Z.; Angiletta, C.J.; Mitchell, C.M.; Baugh, M.E.; Davy, K.P.; Neilson, A.P. A Mediterranean diet does not alter plasma trimethylamine $\mathrm{N}$-oxide concentrations in healthy adults at risk for colon cancer. Food Funct. 2019, 10, 2138-2147. [CrossRef] [PubMed]

159. Gupta, V.K.; Paul, S.; Dutta, C. Geography, Ethnicity or Subsistence-Specific Variations in Human Microbiome Composition and Diversity. Front. Microbiol. 2017, 8, 1162. [CrossRef] [PubMed] 
160. Smits, L.P.; Kootte, R.S.; Levin, E.; Prodan, A.; Fuentes, S.; Zoetendal, E.G.; Wang, Z.; Levison, B.S.; Cleophas, M.C.P.; Kemper, E.M. Effect of Vegan Fecal Microbiota Transplantation on Carnitine- and Choline-Derived Trimethylamine-N-Oxide Production and Vascular Inflammation in Patients with Metabolic Syndrome. J. Am. Heart. Assoc. 2018, 7, e008342. [CrossRef] [PubMed]

161. Thøgersen, R.; Rasmussen, M.K.; Sundekilde, U.K.; Goethals, S.A.; Van Hecke, T.; Vossen, E.; De Smet, S.; Bertram, H.C. Background Diet Influences TMAO Concentrations Associated with Red Meat Intake without Influencing Apparent Hepatic TMAO-Related Activity in a Porcine Model. Metabolites 2020, 10, 57. [CrossRef]

162. Gibson, G.R.; Hutkins, R.; Sanders, M.E.; Prescott, S.L.; Reimer, R.A.; Salminen, S.J.; Scott, K.; Stanton, C.; Swanson, K.S.; Cani, P.D.; et al. Expert consensus document: The International Scientific Association for Probiotics and Prebiotics (ISAPP) consensus statement on the definition and scope of prebiotics. Nat. Rev. Gastroenterol. Hepatol. 2017, 14, 491-502. [CrossRef]

163. Holscher, H.D. Dietary fiber and prebiotics and the gastrointestinal microbiota. Gut Microbes 2017, 8, $172-184$. [CrossRef]

164. Li, Q.; Wu, T.; Liu, R.; Zhang, M.; Wang, R. Soluble Dietary Fiber Reduces Trimethylamine Metabolism via Gut Microbiota and Co-Regulates Host AMPK Pathways. Mol. Nutr. Food. Res. 2017, 61. [CrossRef] [PubMed]

165. Benitez-Paez, A.; Kjølbaek, L.; Gomez Del Pulgar, E.M.; Brahe, L.K.; Astrup, A.; Matysik, S.; Schott, H.F.; Krautbauer, S.; Liebisch, G.; Boberska, J.; et al. A Multi-omics Approach to Unraveling the Microbiome-Mediated Effects of Arabinoxylan Oligosaccharides in Overweight Humans. mSystems 2019, 4, e00209-19. [CrossRef] [PubMed]

166. Zhang, C.; Yin, A.; Li, H.; Wang, R.; Wu, G.; Shen, J.; Zhang, M.; Wang, L.; Hou, Y.; Ouyang, H.; et al. Dietary modulation of gut microbiota contributes to alleviation of both genetic and simple obesity in children. EBioMedicine 2015, 2, 968-984. [CrossRef] [PubMed]

167. Chen, M.L.; Yi, L.; Zhang, Y.; Zhou, X.; Ran, L.; Yang, J.; Zhu, J.D.; Zhang, Q.Y.; Mi, M.T. Resveratrol Attenuates Trimethylamine-N-Oxide (TMAO)-Induced Atherosclerosis by Regulating TMAO Synthesis and Bile Acid Metabolism via Remodeling of the Gut Microbiota. mBio 2016, 7, e02210-15. [CrossRef] [PubMed]

168. Chen, P.Y.; Li, S.; Koh, Y.C.; Wu, J.C.; Yang, M.J.; Ho, C.T.; Pan, M.H. Oolong Tea Extract and Citrus Peel Polymethoxyflavones Reduce Transformation of 1-Carnitine to Trimethylamine-N-Oxide and Decrease Vascular Inflammation in 1-Carnitine Feeding Mice. J. Agric. Food. Chem. 2019, 67, 7869-7879. [CrossRef] [PubMed]

169. Annunziata, G.; Maisto, M.; Schisano, C.; Ciampaglia, R.; Narciso, V.; Tenore, G.C.; Novellino, E. Effects of Grape Pomace Polyphenolic Extract (Taurisolo((R))) in Reducing TMAO Serum Levels in Humans: Preliminary Results from a Randomized, Placebo-Controlled, Cross-Over Study. Nutrients 2019, 11, 139. [CrossRef] [PubMed]

170. Hill, C.; Guarner, F.; Reid, G.; Gibson, G.R.; Merenstein, D.J.; Pot, B.; Morelli, L.; Canani, R.B.; Flint, H.J.; Salminen, S.; et al. Expert consensus document. The International Scientific Association for Probiotics and Prebiotics consensus statement on the scope and appropriate use of the term probiotic. Nat. Rev. Gastroenterol. Hepatol. 2014, 11, 506-514. [CrossRef]

171. Nardone, G.; Compare, D.; Liguori, E.; Di Mauro, V.; Rocco, A.; Barone, M.; Napoli, A.; Lapi, D.; Iovene, M.R.; Colantuoni, A. Protective effects of Lactobacillus paracasei F19 in a rat model of oxidative and metabolic hepatic injury. Am. J. Physiol. Gastrointest. Liver Physiol. 2010, 299, G669-G676. [CrossRef]

172. Ramezani, A.; Nolin, T.D.; Barrows, I.R.; Serrano, M.G.; Buck, G.A.; Regunathan-Shenk, R.; West, R.E., III; Latham, P.S.; Amdur, R.; Raj, D.S. Gut Colonization with Methanogenic Archaea Lowers Plasma Trimethylamine N-oxide Concentrations in Apolipoprotein e-/- Mice. Sci. Rep. 2018, 8, 14752. [CrossRef]

173. Qiu, L.; Yang, D.; Tao, X.; Yu, J.; Xiong, H.; Wei, H. Enterobacter aerogenes ZDY01 attenuates choline-induced trimethylamine $\mathrm{N}$-oxide levels by remodeling gut microbiota in mice. J. Microbiol. Biotechnol. 2017, 27, 1491-1499. [CrossRef]

174. Wos-Oxley, M.; Bleich, A.; Oxley, A.P.; Kahl, S.; Janus, L.M.; Smoczek, A.; Nahrstedt, H.; Pils, M.C.; Taudien, S.; Platzer, M.; et al. Comparative evaluation of establishing a human gut microbial community within rodent models. Gut Microbes 2012, 3, 234-249. [CrossRef] [PubMed]

175. Liubakka, A.; Vaughn, B.P. Clostridium difficile Infection and Fecal Microbiota Transplant. AACN Adv. Crit. Care 2016, 27, 324-337. [CrossRef] [PubMed] 
176. Kump, P.K.; Grochenig, H.P.; Lackner, S.; Trajanoski, S.; Reicht, G.; Hoffmann, K.M.; Deutschmann, A.; Wenzl, H.H.; Petritsch, W.; Krejs, G.J.; et al. Alteration of intestinal dysbiosis by fecal microbiota transplantation does not induce remission in patients with chronic active ulcerative colitis. Inflamm. Bowel Dis. 2013, 19, 2155-2165. [CrossRef]

177. Wang, Z.; Roberts, A.B.; Buffa, J.A.; Levison, B.S.; Zhu, W.; Org, E.; Gu, X.; Huang, Y.; Zamanian-Daryoush, M.; Culley, M.K.; et al. Non-lethal Inhibition of Gut Microbial Trimethylamine Production for the Treatment of Atherosclerosis. Cell 2015, 163, 1585-1595. [CrossRef] [PubMed]

178. Kuka, J.; Liepinsh, E.; Makrecka-Kuka, M.; Liepins, J.; Cirule, H.; Gustina, D.; Loza, E.; Zharkova-Malkova, O.; Grinberga, S.; Pugovics, O.; et al. Suppression of intestinal microbiota-dependent production of pro-atherogenic trimethylamine N-oxide by shifting L-carnitine microbial degradation. Life. Sci. 2014, 117, 84-92. [CrossRef] [PubMed]

179. Kummen, M.; Mayerhofer, C.C.K.; Vestad, B.; Broch, K.; Awoyemi, A.; Storm-Larsen, C.; Ueland, T.; Yndestad, A.; Hov, J.R.; Troseid, M. Gut Microbiota Signature in Heart Failure Defined From Profiling of 2 Independent Cohorts. J. Am. Coll. Cardiol. 2018, 71, 1184-1186. [CrossRef]

180. Pasini, E.; Aquilani, R.; Testa, C.; Baiardi, P.; Angioletti, S.; Boschi, F.; Verri, M.; Dioguardi, F. Pathogenic Gut Flora in Patients with Chronic Heart Failure. JACC Heart Fail. 2016, 4, 220-227. [CrossRef]

181. Shih, D.M.; Wang, Z.; Lee, R.; Meng, Y.; Che, N.; Charugundla, S.; Qi, H.; Wu, J.; Pan, C.; Brown, J.M.; et al. Flavin containing monooxygenase 3 exerts broad effects on glucose and lipid metabolism and atherosclerosis. J. Lipid Res. 2015, 56, 22-37. [CrossRef]

182. Hsu, C.N.; Chang-Chien, G.P.; Lin, S.; Hou, C.Y.; Tain, Y.L. Targeting on Gut Microbial Metabolite Trimethylamine-N-Oxide and Short-Chain Fatty Acid to Prevent Maternal High-Fructose-Diet-Induced Developmental Programming of Hypertension in Adult Male Offspring. Mol. Nutr. Food Res. 2019, 63, e1900073. [CrossRef]

183. Wu, W.-K.; Panyod, S.; Ho, C.-T.; Kuo, C.-H.; Wu, M.-S.; Sheen, L.-Y. Dietary allicin reduces transformation of L-carnitine to TMAO through impact on gut microbiota. J. Func. Food 2015, 15, 408-417. [CrossRef]

184. Bjerrum, J.T.; Nielsen, O.H.; Hao, F.; Tang, H.; Nicholson, J.K.; Wang, Y.; Olsen, J. Metabonomics in ulcerative colitis: Diagnostics, biomarker identification, and insight into the pathophysiology. J. Proteome Res. 2010, 9 , 954-962. [CrossRef] [PubMed]

185. Morgan, X.C.; Tickle, T.L.; Sokol, H.; Gevers, D.; Devaney, K.L.; Ward, D.V.; Reyes, J.A.; Shah, S.A.; Leleiko, N.; Snapper, S.B.; et al. Dysfunction of the intestinal microbiome in inflammatory bowel disease and treatment. Genome Biol. 2012, 13, R79. [CrossRef] [PubMed]

186. Murdoch, T.B.; Fu, H.; Macfarlane, S.; Sydora, B.C.; Fedorak, R.N.; Slupsky, C.M. Urinary metabolic profiles of inflammatory bowel disease in interleukin-10 gene-deficient mice. Anal. Chem. 2008, 80, 5524-5531. [CrossRef]

187. Del Chierico, F.; Nobili, V.; Vernocchi, P.; Russo, A.; De Stefanis, C.; Gnani, D.; Furlanello, C.; Zandona, A.; Paci, P.; Capuani, G.; et al. Gut microbiota profiling of pediatric nonalcoholic fatty liver disease and obese patients unveiled by an integrated meta-omics-based approach. Hepatology 2017, 65, 451-464. [CrossRef] [PubMed]

188. Yun, J.; Yin, Y.; Li, Z.; Zhang, W. Gut microbiota-derived components and metabolites in the progression of non-alcoholic fatty liver disease. Nutrients 2019, 11, 1712. [CrossRef]

189. Fukami, K.; Yamagishi, S.; Sakai, K.; Kaida, Y.; Yokoro, M.; Ueda, S.; Wada, Y.; Takeuchi, M.; Shimizu, M.; Yamazaki, H.; et al. Oral L-carnitine supplementation increases trimethylamine-N-oxide but reduces markers of vascular injury in hemodialysis patients. J. Cardiovasc. Pharmacol. 2015, 65, 289-295. [CrossRef] [PubMed]

190. Mollica, G.; Senesi, P.; Codella, R.; Vacante, F.; Montesano, A.; Luzi, L.; Terruzzi, I. L-carnitine supplementation attenuates NAFLD progression and cardiac dysfunction in a mouse model fed with methionine and choline-deficient diet. Dig. Liver Dis. 2020, 52, 314-323. [CrossRef]

191. Okubo, H.; Sakoda, H.; Kushiyama, A.; Fujishiro, M.; Nakatsu, Y.; Fukushima, T.; Matsunaga, Y.; Kamata, H.; Asahara, T.; Yoshida, Y.; et al. Lactobacillus casei strain Shirota protects against non-alcoholic steatohepatitis development in a rodent model. Am. J. Physiol. Gastrointest. Liver Physiol. 2013, 305, G911-G918. [CrossRef]

192. Ley, R.E.; Turnbaugh, P.J.; Klein, S.; Gordon, J.I. Microbial ecology: Human gut microbes associated with obesity. Nature 2006, 444, 1022-1023. [CrossRef]

193. Meyer, K.A. Population Studies of TMAO and Its Precursors May Help Elucidate Mechanisms. Am. J. Clin. Nutr. 2020, 111, 1115-1116. [CrossRef] 
194. Fu, B.C.; Hullar, M.A.J.; Randolph, T.W.; Franke, A.A.; Monroe, K.R.; Cheng, I.; Wilkens, L.R.; Shepherd, J.A.; Le Marchand, L.; Lim, U.; et al. Associations of plasma trimethylamine N-oxide (TMAO), choline, carnitine, and betaine with inflammatory and cardiometabolic risk biomarkers and the fecal microbiome in the Multiethnic Cohort Adiposity Phenotype Study. Am. J. Clin. Nutr. 2020, 111, 1226-1234. [CrossRef] [PubMed]

195. Heianza, Y.; Ma, W.; Manson, J.A.E.; Rexrode, K.M.; Qi, L. Gut microbiota metabolites and risk of major adverse cardiovascular disease events and death: A systematic review and meta-analysis of prospective studies. J. Am. Heart Assoc. 2017, 6, e004947. [CrossRef] [PubMed]

196. Bekdash, R.A. Neuroprotective Effects of Choline and Other Methyl Donors. Nutrients 2019, 11, 2995. [CrossRef] [PubMed]

(C) 2020 by the authors. Licensee MDPI, Basel, Switzerland. This article is an open access article distributed under the terms and conditions of the Creative Commons Attribution (CC BY) license (http://creativecommons.org/licenses/by/4.0/). 